\title{
3',8'-Biisokaempferide, a Cytotoxic Biflavonoid and Other Chemical Constituents of Nanuza plicata (Velloziaceae)
}

\author{
Meri Emili F. Pinto, ${ }^{a}$ Marcelo Sobral da Silva, ${ }^{* a}$ Elisabete Schindler, ${ }^{b}$ José Maria \\ Barbosa Filho, ${ }^{a}$ Ramon dos Santos El-Bacha, ${ }^{b}$ Marianna Vieira S. Castello-Branco, ${ }^{a}$ \\ Maria de Fatima Agra ${ }^{a}$ and Josean Fechine Tavares ${ }^{a}$
}

${ }^{a}$ Laboratório de Tecnologia Farmacêutica, Universidade Federal da Paraíba, CP 5009, 58051-970 João Pessoa-PB, Brazil

${ }^{b}$ Laboratório de Neuroquímica e Biologia Celular (LabNq), Instituto de Ciências da Saúde (ICS), Universidade Federal da Bahia, 40110-902 Salvador-BA, Brazil

\begin{abstract}
Foi isolado das folhas de Nanuza plicata um novo biflavonóide, chamado 3',8"-biisocampferideo (1), juntamente com os conhecidos compostos amentoflavona (2), ácido patagônico (3), (4aR,5S,6R,8aR)-5-[2-(2,5-dihidro-5-metóxi-2-oxofuran-3-il)etil]-3,4,4a,5,6,7,8, 8a-octahidro-5,6,8a-trimetilnaftaleno-1-ácido carboxílico (4), cafeoilquinato de metila (5), ácido 3,5-di-cafeoilquínico (6) e luteolina (7). Os compostos 3, 4, 5 e $\mathbf{6}$ são relatados pela primeira vez em Velloziaceae. As estruturas dos compostos foram elucidadas com base em métodos espectroscópicos, especialmente RMN e EM. A citotoxicidade de 3',8'-biisocampferideo foi estudada em células de glioblastoma humano (GL-15). A concentração efetiva, que produziu morte em $50 \%$ das células após $72 \mathrm{~h}$ foi $36,5 \mu \mathrm{mol} \mathrm{L}^{-1}$. Alterações na morfologia celular, incluindo retração e degradação de citoplasma, foram observadas quando as células foram tratadas com concentrações a partir de $20 \mu \mathrm{mol} \mathrm{L} \mathrm{L}^{-1}$ de 3',8'"-biisocampferideo por $72 \mathrm{~h}$.
\end{abstract}

A novel biflavonoid, named 3',8"-biisokaempferide (1), along with the known compounds amentoflavone (2), patagonic acid (3), (4aR,5S,6R,8aR)-5-[2-(2,5-Dihydro-5-methoxy-2-oxofuran3-yl)ethyl]-3,4,4a,5,6,7,8,8a-octahydro-5,6,8a-trimethylnaphthalene-1-carboxylic acid (4), 5-caffeoylquinic acid methyl ester (5), 3,5-di-caffeoylquinic acid (6) and luteolin (7), were isolated of the leaves from Nanuza plicata. The compounds $3,4,5$ and $\mathbf{6}$ are reported for the first time in Velloziaceae. The structures of the compounds were elucidated on the basis of spectroscopic methods, especially NMR and MS analyses. The cytotoxicity of 3',8"'-biisokaempferide was studied in cultures of human glioblastoma GL-15 cells. The effective concentration, which killed $50 \%$ of cells after $72 \mathrm{~h}$ was $36.5 \mu \mathrm{mol} \mathrm{L} \mathrm{L}^{-1}$. Changes in cellular morphology, including retraction and degradation of cytoplasm, were observed when cells were treated with concentrations from $20 \mu \mathrm{mol} \mathrm{L}{ }^{-1}$ of 3', 8' -biisokaempferide for $72 \mathrm{~h}$.

Keywords: 3',8'"-biisokaempferide, Nanuza plicata, cytotoxicity, Velloziaceae

\section{Introduction}

Velloziaceae is a family of monocotyledonous plants containing about 270 species of the tropical Brazilian flora occurring in rocky fields. ${ }^{1}$ These plants live under conditions of high solar irradiation and low water availability. ${ }^{2}$ Species of this family contain high amounts of diterpenes with a skeleton of the clerodane, ${ }^{2}$ cleisthantane, isopimarane, ${ }^{3}$ kaurane,${ }^{4}$ and labdane ${ }^{5}$ types,

*e-mail: marcelosobral@1tf.ufpb.br besides flavonoids monoisoprenylated, $C$-alkylated and biflavonoids. ${ }^{6-9}$ The genus Nanuza comprises three species, N. plicata, N. almeidae and N. luetzelburgii. Nanuza plicata (Mart.) L. B. Sm. \& Ayensu (Synonymy: Vellozia plicata and Xerophyta plicata), is known commonly as "canela d'ema". In earlier studies the compounds 3-geranyl-4-hydroxybenzoate ${ }^{10-11}$ and the biflavonoid amentoflavone, ${ }^{12}$ were isolated from species collected in the States of Rio de Janeiro and Minas Gerais, Brazil, respectively. In this work, we report the isolation and structure elucidation of the following compounds: two 
biflavonoids, 3',8"-biisokaempferide (1), a new natural product, and amentoflavone (2), ${ }^{13}$ two diterpenes of the clerodane type, patagonic acid (3) $)^{14}$ and $(4 \mathrm{aR}, 5 \mathrm{~S}, 6 \mathrm{R}, 8 \mathrm{aR})$ 5-[2-(2,5-dihydro-5-methoxy-2-oxofuran-3-yl)ethyl]$3,4,4 a, 5,6,7,8,8 \mathrm{a}$-octahydro-5,6,8a trimethylnaphthalene1-carboxylic acid (4), ${ }^{15}$ two caffeoylquinic acid derivates, 5 -caffeoylquinic acid methyl ester $(5)^{16}$ and 3,5-dicaffeoylquinic acid (6) ${ }^{17-18}$ and a flavone, luteolin (7) ${ }^{19}$ (Figure 1). The compounds $\mathbf{3 , 4 , 5}$ and $\mathbf{6}$ are reported for the first time in Velloziaceae.

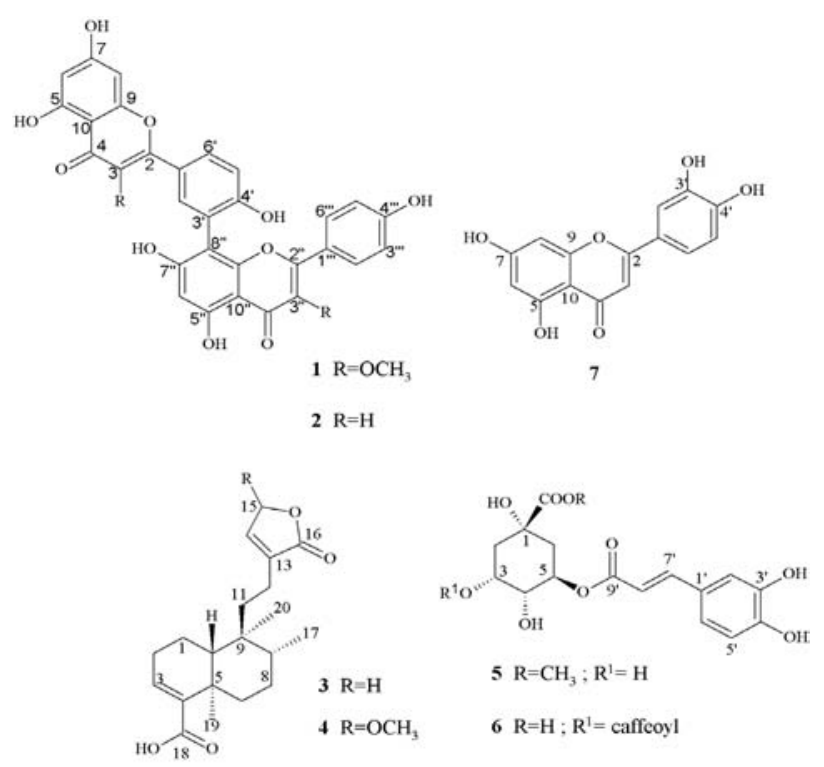

Figure 1. Chemical constituents of Nanuza plicata.

Interest in the possible health benefits of flavonoids has increased because some human feeding studies support a protective effect of their consumption in cancer ${ }^{20}$ and also against cytotoxic insults induced by oxidative stress and amyloid $\mathrm{b}$ suggesting their therapeutic potential against neurodegenerative diseases. ${ }^{21}$ The replacement of animal techniques with non-animal ones is imperative in safe toxicological evaluations of new compounds. Models using cultured cells to evaluate the cytotoxicity of chemicals have the advantage of being simple and quick with a low evaluation cost. ${ }^{22}$ The investigation of new molecules for glioblastoma treatment is relevant because despite current advances in therapy, including surgical resection followed by radiation and chemotherapy, the prognosis for patients remains poor. ${ }^{23}$ In this paper, the cytotoxicity of $\mathbf{1}$ to human glioblastoma GL-15 cells was evaluated in vitro.

\section{Results and Discussion}

The ethanol extract from N. plicata afforded flavonoids, clerodane diterpenes and derivatives of chlorogenic acid.
The new biflavonoid (1) was isolated in the form of a yellow solid with mp $340-342^{\circ} \mathrm{C}$, and the HR-ESI-MS mass spectrum showed a molecular ion peak at $599.5331[\mathrm{M}+$ $\mathrm{H}$ ] , compatible with the molecular formula $\mathrm{C}_{32} \mathrm{H}_{23} \mathrm{O}_{12}$. The infrared spectrum in $\mathrm{KBr}$ showed absorption at 3350, 3250 and $1651 \mathrm{~cm}^{-1}$, characteristic of $\mathrm{OH}$ and carbonyl groups, respectively. The ${ }^{13} \mathrm{C}$ NMR in $\mathrm{CD}_{3} \mathrm{OD}(500 \mathrm{MHz})$ showed the presence of 32 signals where 20 signals were attributed to non-hydrogenated carbons, 8 signals corresponding to 10 methynic carbons and 2 to methoxy carbons. The chemical shifts at $\delta_{\mathrm{C}} 180.0$ and 179.9 confirm the absorption of carbonyl groups. The signals at $\delta_{\mathrm{C}} 94.8$ and 99.8 , compared with literature data ${ }^{19}$ were attributed to C- 8 and C-6, respectively, of the flavonoids A ring. Likewise, the signals at $\delta_{\mathrm{C}} 121.9,106.8$ and 101.4 were attributed to C-3', C-8" and C-6" consistent with biflavonoids bond C-3'-C-8", because when fusion is C-3'-C-6", the chemical shifts for the same carbons are 116.7, 93.9 and 103.5, respectively. The bond C-3'-C-8" was confirmed by the HMBC correlations of the signal at 6.31 (s, H-6"), and 7.08 (d, J 9.0, H-5') with 106.8 (C -8").

The absence of carbon signals at $\delta_{\mathrm{C}} 104.0$ and 103.4, as in amentoflavone (2), and the chemical shifts for the methoxy carbons at $\delta_{\mathrm{C}} 60.5$ and 60.6 and comparison with the chemical shifts of isokaempferide ${ }^{19}$ suggest the insertion of these groups at C-3 and C-3". This notion was confirmed by the HMBC spectrum through the correlations of the methoxy hydrogens with the carbons at $\delta_{\mathrm{C}} 139.4$ and 139.3 (C-3 and C-3"). It is further supported by the ROESY spectrum through the correlations of the methoxy protons at C-3 and C-3" with the hydrogens H-6' and H-2"', respectively. Thus, (1) differs from amentoflavone by having positions C-3 and C-3" occupied by methoxy groups. By comparing the chemical shifts of monomeric units of (1) with the literature could be characterized them as units isokaempferide. Therefore, (1) is a new biflavonoid with union C-3'-C-8" of isokaempferide, named $3^{\prime}, 8$ "'-biisokaempferide. The data for ${ }^{1} \mathrm{H},{ }^{13} \mathrm{C}, \mathrm{HMQC}$ and HMBC NMR are compiled in Table 1. The known flavonoid amentoflavone (2) was identified by spectral data analysis and comparison with literature values. ${ }^{19}$ The structures of $\mathbf{3}$ and $\mathbf{4}$ were identified by NMR as patagonic acid ${ }^{14}$ and (4aR,5S,6R,8aR)-5-[2-(2,5-dihydro-5-methoxy-2oxofuran-3-yl)ethyl]-3,4,4a,5,6,7,8,8a-octahydro-5,6,8atrimethylnaphthalene-1-carboxylic acid, respectively, both diterpenes of the clerodane type. ${ }^{15,24,25}$ According to the literature ${ }^{14}$ on substance 3 the chemical shifts of C- 2 is 27.4 and $\mathrm{C}-7$ is 27.2. HMBC spectrum showed a correlation of the signal at $0.85\left(\mathrm{~d}, J 6.7 \mathrm{~Hz}, \mathrm{CH}_{3}-17\right)$ with the signal at 27.2 , being this signal assigned to $\mathrm{C}-7$, and a correlation of the signal at 6.81 (br s H-3) with the signal at 27.4, 
Table 1. NMR data for $\mathbf{1}^{\mathrm{a}}$

\begin{tabular}{|c|c|c|c|}
\hline Positions & HMQC & & НMBC \\
\hline & ${ }^{1} \mathrm{H}$ & ${ }^{13} \mathrm{C}$ & \\
\hline 2 & - & 158.1 & \\
\hline 3 & - & 139.4 & \\
\hline 4 & - & 180.0 & \\
\hline 5 & - & 162.9 & \\
\hline 6 & $6.14(\mathrm{~d}, J 2.0)$ & 99.8 & C-5, C-7, C-10 \\
\hline 7 & - & 166.2 & \\
\hline 8 & $6.19(\mathrm{~d}, J 2.0)$ & 94.8 & $\mathrm{C}-7, \mathrm{C}-9, \mathrm{C}-10$ \\
\hline 9 & - & 158.4 & \\
\hline 10 & - & 105.7 & \\
\hline 1 ' & - & 122.7 & \\
\hline 2 & $8.16(\mathrm{~d}, J 2.0)$ & 134.6 & C-2, C-4', C-6', C-8"' \\
\hline $3^{\prime}$ & - & 121.9 & \\
\hline $4^{\prime}$ & - & 161.1 & \\
\hline 5 , & $7.08(\mathrm{~d}, J 9.0)$ & 118.4 & $\mathrm{C}-1^{\prime}, \mathrm{C}-3^{\prime}, \mathrm{C}-4^{\prime}$ \\
\hline 6 & $8.08(\mathrm{dd}, J 9.0 ; 2.0)$ & 130.4 & $\mathrm{C}-4$ \\
\hline $2 "$ & - & 157.2 & \\
\hline $3 "$ & - & 139.3 & \\
\hline $4 "$ & - & 179.9 & \\
\hline $5 "$ & - & 162.1 & \\
\hline $6 "$ & $6.31(\mathrm{~s})$ & 101.4 & C-5", C-7", C-8" \\
\hline $7 "$ & - & 167.5 & \\
\hline $8 "$ & - & 106.8 & \\
\hline $9 "$ & - & 155.6 & \\
\hline $10 "$ & - & 105.2 & \\
\hline $1 "$, & - & 122.6 & \\
\hline $2 "$ & $7.78(\mathrm{~d}, J 8.0)$ & 131.3 & C-2", C-4"” \\
\hline $3 " ”$ & $6.65(\mathrm{~d}, J$ 8.0) & 116.3 & C-1"', C-4"” \\
\hline $4 "$, & - & 161.4 & \\
\hline $5 "$, & $6.65(\mathrm{~d}, J 8.0)$ & 116.3 & C-4"” \\
\hline $6 "$ & $7.78(\mathrm{~d}, J 8.0)$ & 131.3 & C-2', C-4"' \\
\hline $3-\mathrm{OCH}_{3}$ & $3.73(\mathrm{~s})$ & 60.5 & $\mathrm{C}-3$ \\
\hline $3 "-\mathrm{OCH}_{3}$ & $3.78(\mathrm{~s})$ & 60.6 & $\mathrm{C}-3 "$ \\
\hline $5-\mathrm{OH}$ & $12.74(\mathrm{~s})^{\mathrm{b}}$ & - & \\
\hline $5 "-\mathrm{OH}$ & $12.86(\mathrm{~s})^{\mathrm{b}}$ & - & \\
\hline
\end{tabular}

a Data obtained at $500 \mathrm{MHz}, \mathrm{CD}_{3} \mathrm{OD} ; J$ in $\mathrm{Hz}$ and $\delta$ in ppm; ${ }^{\text {b Values }}$ obtained in DMSO- $d_{6}$.

which was assigned to $\mathrm{C}-2$. Thus, ${ }^{13} \mathrm{C}$ NMR data of $\mathbf{3}$ were unequivocally marked.

The spectral data analysis of $\mathbf{5}$ and $\mathbf{6}$ identified these compounds as 5-caffeoylquinic acid methyl ester ${ }^{26}$ and 3,5-dicaffeoylquinic acid, ${ }^{18}$ respectively, both reported for the first time in the family Velloziaceae. Luteolin (7) was identified by spectral data analysis and comparison with literature values. ${ }^{19}$
The effect of the concentration of compound $\mathbf{1}$ on the induction of cytotoxicity to human glioblastoma GL-15 cells was investigated (Figure 2). It was found that the minimal cytotoxic concentration was $20 \mu \mathrm{mol} \mathrm{L}^{-1}$ as compared to control group, killing $46.9 \%$ of cells after 72 h 3', 8"'-biisokaempferide -induced cytotoxicity was fitted to equation 1 :

$$
\begin{array}{r}
\mathrm{V}=4.987+\left\{115.113 /\left[1+10^{(1.991 \log [\mathrm{C}]-2.919)}\right]\right\} \\
\left(\mathrm{R}^{2}=0.9262\right)
\end{array}
$$

in which $\mathrm{V}$ corresponds to cell viability normalized to data measured under control conditions, and $[\mathrm{C}]$ is the 3',8''-biisokaempferide concentration. The calculated effective concentration, which killed 50\% $\left(\mathrm{EC}_{50}\right)$ of GL-15 cells after $72 \mathrm{~h}$ was $36.5 \mu \mathrm{mol} \mathrm{L} \mathrm{L}^{-1}$.

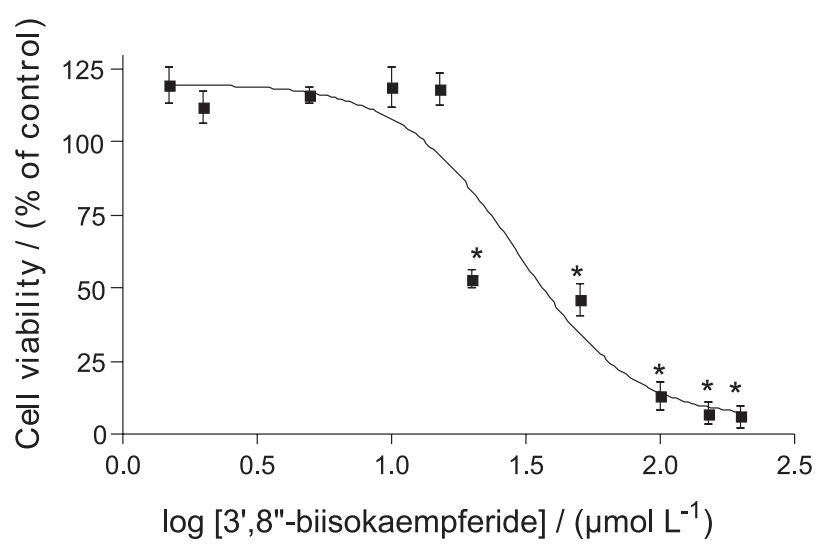

Figure 2. 3',8"'-biisokaempferide induced cytotoxicity to human glioblastoma GL-15 cells. GL-15 cells were exposed to 3',8"'-biisokaempferide $1.5-200 \mu \mathrm{mol} \mathrm{L}-1$ for $72 \mathrm{~h}$, at $37{ }^{\circ} \mathrm{C}$, and $5 \% \mathrm{CO}_{2}$, in 96 -well plates ( $\mathrm{n}=8$ for each concentration). Cell viability was normalized to data measured under control conditions without 3 ', 8 "'-biisokaempferide. ${ }^{*} p<0.05$ versus control cells.

This is important to state that the same investigation carried out with amentoflavone showed that it does not possess any antitumoral activity against GL-15 cells until $600 \mu \mathrm{mol} \mathrm{L}^{-1}$ (data not shown). Since the difference between these compounds shown in formulas $\mathbf{1}$ and $\mathbf{2}$ (Figure 1) is the presence of two methoxy carbons, these groups enhance the induction of cytotoxicity to GL-15 cells.

The morphology of cells treated with $1.5 \mu \mathrm{mol} \mathrm{L}^{-1}$ 3',8',-biisokaempferide was not modified after $72 \mathrm{~h}$, when compared to the negative control group. Changes in cellular morphology were observed when cells were treated with $20 \mu \mathrm{mol} \mathrm{L}^{-1} 3^{\prime}, 8$ "'-biisokaempferide for $72 \mathrm{~h}$, some cells showed retraction and degradation of cytoplasm, others became round and big. Furthermore, some cells detached from plates. Cells treated with $200 \mu \mathrm{mol} \mathrm{L} \mathrm{L}^{-1}$ 3',8',-biisokaempferide for $72 \mathrm{~h}$ presented an almost 
complete degradation of cytoplasm, characterizing cellular death.

Temozolomide (TMZ) was the first chemotherapeutic agent approved for treatment of high-grade malignant gliomas in more than 20 years. In primary culture of human glioblastoma cells, differences in TMZ cytotoxicity was observed, the individualized $\mathrm{EC}_{50}$ after $72 \mathrm{~h}$ showed variability between patients, $450-900 \mathrm{mmol} \mathrm{L}{ }^{-1} \cdot{ }^{27}$ Although relatively uncommon, malignant gliomas are associated with disproportionately high morbidity and mortality, and despite optimal treatment, the median survival is only 12 to 15 months for patients with glioblastoma. ${ }^{28}$ Glioblastoma stem cells display strong capability of tumor's resistance to

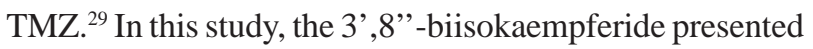
an $\mathrm{EC}_{50}$ of $36.5 \mu \mathrm{mol} \mathrm{L} \mathrm{L}^{-1}$ in GL-15 cells, a cytotoxic concentration beneath that found for TMZ. ${ }^{27}$

\section{Experimental}

\section{General procedures}

Melting points have not been corrected. IR spectra were recorded on a BOMEM-MB 100 spectrophotometer. ${ }^{1} \mathrm{H}$ $(500 \mathrm{MHz})$ and ${ }^{13} \mathrm{C}(125 \mathrm{MHz}) \mathrm{NMR}$ spectra were recorded on a VARIAN-System spectrometer using DMSO- $d_{6}$, $\mathrm{CD}_{3} \mathrm{OD}$ or $\mathrm{CDCl}_{3}$ with TMS as internal standard. HRESI mass spectra were obtained with a Brüker Daltonics UltrOTOF-Q, Billerica, MA, spectrometer using $\left(\mathrm{H}_{2} \mathrm{O}\right.$, $\mathrm{Ar}), 20 \mathrm{eV}$ for $\mathrm{MS}$ and $45 \mathrm{eV}$ for MS/MS in positive mode. Column chromatography with silica gel (Merck 0.063-0.20 $\mathrm{mm}$ ) and Sephadex LH-20 (Sigma, USA); silica gel F254 $\mathrm{G}$ (Vetec) was used for preparative TLC, silica gel plates $\mathrm{PF}_{254} 7749$ (Merck) was used for analytical TLC; with visualization under UV (254 and $366 \mathrm{~nm}$ ), or exposure to iodine vapor.

\section{Plant material}

The entire plant of Nanuza plicata (Mart.) L.B.Sm. \& Ayensu (Velloziaceae) was collected in March 2007 in the semi-arid northeast region of Brazil, city of Serra Branca in Paraiba State. Voucher specimen (Agra et al.; 5730) is deposited at the Herbarium Prof. Lauro Pires Xavier, Universidade Federal da Paraíba, João Pessoa-PB, Brazil.

\section{Extraction and isolation}

The dry and pulverized plant material $(2.0 \mathrm{~kg})$ was extracted successively with $95 \%$ ethanol at room temperature. The solvent was removed under reduced pressure, obtaining the crude ethanol extract $(60 \mathrm{~g})$.
Eight grams of this extract were submitted to gel filtration through Sephadex LH 20, eluted with methanol followed by a methanol:chloroform (1:1), resulting in 76 fractions (A1-A76). The eluate from the column was monitored by analytical thin-layer chromatography and similar fractions were combined. The group of fractions A5-A7 (35 mg) was submitted to preparative TLC with chloroform:methanol (9:1), obtaining $1(20 \mathrm{mg})$. The group of fractions A8-A9 $(25 \mathrm{mg})$ was recrystallized from acetone obtaining $2(15 \mathrm{mg})$. The fractions A10-A13 (100 mg) were chromatographed on a silica gel column utilizing chloroform:methanol as the mobile phase, with an increasing polarity gradient, obtaining 3 and $4(10 \mathrm{mg}), 5(11 \mathrm{mg})$ and $\mathbf{6}(12 \mathrm{mg})$, respectively. The group of fractions A23-A28 was recrystallized from acetone, obtaining 7 (8 $\mathrm{mg})$.

\section{Glioblastoma cell cultures}

Experiments were carried out using human glioblastoma GL-15 cell line of clonal origin, which has been previously established. ${ }^{30}$ GL-15 cell cultures were prepared as described previously. ${ }^{31}$ Cells were grown in a humidified $95 \%$ air and $5 \% \mathrm{CO}_{2}$ atmosphere at $37^{\circ} \mathrm{C}$, and the culture medium was replaced three times a week. At the time of the experiment, confluent cells were trypsinized and plated in a 96-well plate, at a final density of $3 \times 10^{4} \mathrm{cells} / \mathrm{cm}^{2}$. Experiments were initiated $72 \mathrm{~h}$ after plating.

In vitro evaluation of 3',8'-biisokaempferide induced cytotoxicity

3', 8'-biisokaempferide at concentrations between 1.5-200 $\mathrm{mmol} \mathrm{L}^{-1}$, and amentoflavone at concentrations between 3-600 $\mathrm{mmol} \mathrm{L}^{-1}$ were used to examine its cytotoxic effects. Eight replicates were used for each dose in a 96-well plate. Cells were exposed to 1 for $72 \mathrm{~h}$. Cells viability was assessed using 3-(4,5-dimethylthiazol2-yl)-2,5-diphenyltetrazolium bromide (MTT; Sigma, St. Louis, MO). MTT was dissolved at a concentration of $5 \mathrm{mg} \mathrm{L}^{-1}$ in sterile phosphate buffered saline (PBS) at room temperature, and the solution was further sterilized by passing through a $0.2 \mathrm{~mm}$ filter and stored at $4{ }^{\circ} \mathrm{C}$ in the dark. The final concentration of MTT added to each well was $1 \mathrm{mg} \mathrm{L}^{-1}$. After $2 \mathrm{~h}$ of incubation at $37^{\circ} \mathrm{C}$, a same volume of lysis buffer was added. Lysis buffer was prepared as follows: $20 \%(\mathrm{~m} / \mathrm{v})$ sodium dodecyl sulphate (SDS) was dissolved at $37{ }^{\circ} \mathrm{C}$ in a solution of $50 \%(\mathrm{v} / \mathrm{v})$ dimethylformamide (DMF) and reagent grade water, $\mathrm{pH} 4.7$. After an overnight incubation at room temperature, optical densities were measured at $580 \mathrm{~nm}$. Cell viability was 
normalized to data measured under control conditions, without 1.

\section{Phase contrast microscopy}

Cell morphology was evaluated by phase contrast microscopy using an inverted microscope Eclipse TS100 (Nikon, Tokyo, Japan). Photographs were taken by a Coolpix 4300 digital camera (Nikon) attached to the microscope. Nikon View version 6.1.0 was used to transfer images from the camera to a computer to be edited. The only process used to edit images was to transform color photographs into halftone pictures. A ruler with ticks every $10 \mathrm{~mm}$ (Olympus, Tokyo, Japan) was photographed under the same conditions. A new layer containing the ruler was added to pictures using Photo Impression 4.0 (ArcSoft, Fremont, USA).

\section{Statistical analysis}

The data for the concentration-response curve were analyzed using one-way ANOVA and groups were compared by Student-Newman-Keuls test. The data were fitted using nonlinear regression performed with GraphPad Prism software (San Diego, USA).

\section{3',8"-biisokaempferide (1)}

Yellow amorphous powder; IR (KBr) $v_{\max } / \mathrm{cm}^{-1}: 3350$, 1651, 1500, 1357, 1980; HRMS-ESI $\mathrm{m} / \mathrm{z}: 599.5331$ $(\mathrm{M}+\mathrm{H})^{+}$, (calc. for $\mathrm{C}_{32} \mathrm{H}_{23} \mathrm{O}_{12}$ 599.5389), found 464.3662 (100\%); ${ }^{1} \mathrm{H}$ and ${ }^{13} \mathrm{C}$ NMR spectral data: see Table 1.

\section{Patagonic acid (3)}

White amorphous powder; IR (KBr) $v_{\max } / \mathrm{cm}^{-1}: 3433$, 2958, 1751, 1678, 1458, 1261; ${ }^{1} \mathrm{H} \mathrm{NMR}\left(\mathrm{CDCl}_{3} ; 500 \mathrm{MHz}\right)$ : $\delta 1.70$ (m, 2H-1), 1.45 (m, 2H-2), 6.81 (br s, H-3), 1.43 (m, H-6eq), 2.40 (m, H-6ax), 2.25 (m, 2H-7), 1.50 (m, H-8), 1.35 (m, H-10), 1.19 (m, H-11eq), 2.40 (m, H-11ax), 2,05 (m, H-12eq), 2.20 (m, H-12ax), 7.06 (br s, H-14), 4.79 (br s, 2H-15), 0.85 (d, 3H-17), 1.27 (s, 3H-19), 0.75 (s, 3H20); NMR $\left(\mathrm{CDCl}_{3} ; 500 \mathrm{MHz}\right): \delta 17.4\left(\mathrm{CH}_{2}-1\right), 27.4\left(\mathrm{CH}_{2}-\right.$ 2), 140.1 (CH-3), 141.1 (C-4), 37.4 (C-5), $36.0\left(\mathrm{CH}_{2}-6\right)$, $27.2\left(\mathrm{CH}_{2}-7\right), 36.3$ (CH-8), 38.7 (C-9), 46.7 (CH-10), 35.7 $\left(\mathrm{CH}_{2}-11\right), 19.0\left(\mathrm{CH}_{2}-12\right), 135.0(\mathrm{C}-13), 143.4(\mathrm{CH}-14)$, $70.1\left(\mathrm{CH}_{2}-15\right), 174.3(\mathrm{C}-16), 15.8\left(\mathrm{CH}_{3}-17\right), 174.2(\mathrm{C}-18)$, $20.5\left(\mathrm{CH}_{3}-19\right), 18.1\left(\mathrm{CH}_{3}-20\right)$.

\section{Supplementary Information}

Supplementary data are available free of charge at http://jbcs.sbq.org.br, as PDF file.

\section{Acknowledgments}

The authors are grateful to CNPq, FAPESB and CAPES for scholarships and financial support, as well as to V. C. de O. Costa (UFPB) for the NMR spectra, and N. P. Lopes of Faculdade de Ciências Farmacêuticas-USP-Ribeirão Preto for the HR-ESIMS.

\section{References}

1. Stannard, B. L.; Flora of the Pico das Almas: Chapada da Diamantina, Whitstable Litho Ltd: Great Britain, 1995.

2. Pinto, A. C.; Epifânio, R. A.; Zocher, D. H. T.; Biochem. Syst. Ecol. 2004, 32, 597.

3. Pinto, A. C.; Patitucci, M. L.; Silva, R. S.; Queiroz, P. P. S.; Kelecon, A.; Tetrahedron 1983, 39, 3351.

4. Pinto, A. C.; Pinchin, R.; Prado, S. K.; Phytochemistry 1983, 22, 2017.

5. Branco, A.; Pinto A. C.; Braz-Filho, R.; An. Acad. Bras. Cienc. 2004, 76, 505.

6. Branco, A.; Pereira, A. S.; Cardoso, J. N.; Aquino-Neto, F. R.; Pinto, A. C.; Braz-Filho, R.; Phytochem. Anal. 2001, 12, 266.

7. Branco, A.; Pinto, A. C.; Ifa, D. R.; Braz-Filho, R.; J. Braz. Chem. Soc. 2002, 13, 318.

8. Salatino, A.; Salatino, M. L. F.; Santos, D. Y. A. C.; Patrício, M. C. B.; Genet. Mol. Biol. 2000, 23, 931.

9. Williams, C. A.; Harborne, J. B.; Menezes, N. L.; Biochem. Syst. Ecol. 1991, 19, 483.

10. Riehl, C. A. S.; Pinto, A. C.; Figueroa-Villar, J. D; Nat. Prod. Res. 2006, 20, 1225.

11. Riehl, C. A. S.; Pinto, A. C.; Kaiser, C. R.; Figueroa-Villar, J. D.; Cruz, E. R.; Spectrosc. Lett. 2000, 33, 643.

12. Williams, C. A.; Harborne, J. B.; Tomas-Barberan, F. A.; Phytochemistry 1987, 26, 2553.

13. Markham, K. R.; Sheppard, C.; Geiger, H.; Phytochemistry 1987, 26, 3335.

14. Rivera, A. P.; Faini, F.; Castillo, M.; J. Nat. Prod. 1988, 51, 155.

15. Krishna, V.; Singh, P.; Phytochemistry 1999, 52, 1341.

16. Barron, D.; Kaouadji, M.; Mariotte, A. M.; Z. Naturforsch. 1984, 39, 167.

17. Timmermann, B. N.; Hoffman, J. J.; Jolad, S. D.; Schram, K. H.; Klenck, R. E.; Bates, R. B.; J. Nat. Prod. 1983, 46, 365.

18. Meira, M.; David, J. M.; David, J. P.; Araújo, S. V.; Regis, T. L.; Giulietti, A. M.; Queiróz, L. P.; Quim. Nova 2008, 31, 751 .

19. Agrawal, P. K.; Carbons-13 NMR offlavonoids, Elsevier: New York, 1986.

20. Ross, J. A.; Kasum, C. M.; Annu. Rev. Nutr. 2002, 22, 19. 
21. Kang, S. S.; Lee, J. Y.; Choi, Y. K.; Song, S. S.; Kim, J. S.; Jeon, S. J.; Han, Y. N.; Sonc, K. H.; Hana, B. H.; Bioorg. Med. Chem. Lett. 2005, 15, 3588.

22. Matsuda, S.; Hisama, M.; Shibayama, H.; Itou, N.; Iwaki, M.; Yakugaku Zasshi 2009, 129, 1113. (Coden: YKKZAJ ISSN: 0031-6903, AN 2009: 1314869 CaPlus).

23. Valensin, S.; Ghiron, C.; Lamanna, C.; Kremer, A.; Rossi, M.; Ferruzzi, P.; Nievo, M.; Bakker, A.; BMC Cancer 2009, 9, 196.

24. Santos, A. G.; Perez, C. C.; Tininis, A. G.; Bolzani, V. S.; Cavalheiro, A. J.; Quim. Nova 2007, 30, 1100.

25. Ahmad, V. U.; Khan, A.; Farooq, U.; Kousar, F.; Khan, S. S.; Nawaz, S. A.; Abbasi, M. A.; Choudhary, M. I.; Chem. Pharm. Bul. 2005, 53, 378.

26. Rumbero-Sanchez, A.; Vazquez, P.; Phytochemistry 1991, 30, 311.
27. Pédeboscq, S.; L'Azou, B.; Liguoro, D.; Pometan, J. P.; Cambar, J.; Exp. Toxicol. Pathol. 2007, 58, 247.

28. Wen, P. Y.; Kesari, S.; N. Engl. J. Med. 2008, 359, 492.

29. Fu, Z.-G. J.; Liu, X.-M.; Liu, F.-R.; Chen, H.-L.; Shi, J. C.-S.; Pang, H.-K.; Chen Ng, Z.-P.; Chin. Med. J. 2009, 122, 1255.

30. Bocchini, V.; Casalone, R.; Collini, P.; Rebel, G.; Lo Curto, F.; Cell Tissue Res. 1991, 265, 73.

31. Planchenault, T.; Costa, S. L.; Fages, C.; Riche, D.; CharriéreBertrand, C.; Perzelova, A.; Barlovatz-Meimon, G.; Tardy, M. Neurosci. Lett. 2001, 299, 140.

Submitted: December 18, 2009

Published online: June 11, 2010 


\section{3',8'-Biisokaempferide, a Cytotoxic Biflavonoid, and Other Chemical Constituents of Nanuza plicata (Velloziaceae)}

Meri Emili F. Pinto, ${ }^{a}$ Marcelo Sobral da Silva, ${ }^{* a}$ Elisabete Schindler, ${ }^{b}$ José Maria Barbosa Filho, ${ }^{a}$ Ramon dos Santos El-Bachá, ${ }^{b}$ Marianna Vieira S. Castello-Branco, ${ }^{a}$ Maria de Fatima Agra ${ }^{a}$ and Josean Fechine Tavares ${ }^{a}$

${ }^{a}$ Laboratório de Tecnologia Farmacêutica, Universidade Federal da Paraíba, CP 5009, 58051-970 João Pessoa-PB, Brazil

${ }^{b}$ Laboratório de Neuroquímica e Biologia Celular (LabNq), Instituto de Ciências da Saúde (ICS), Universidade Federal da Bahia, 40110-902 Salvador-BA, Brazil

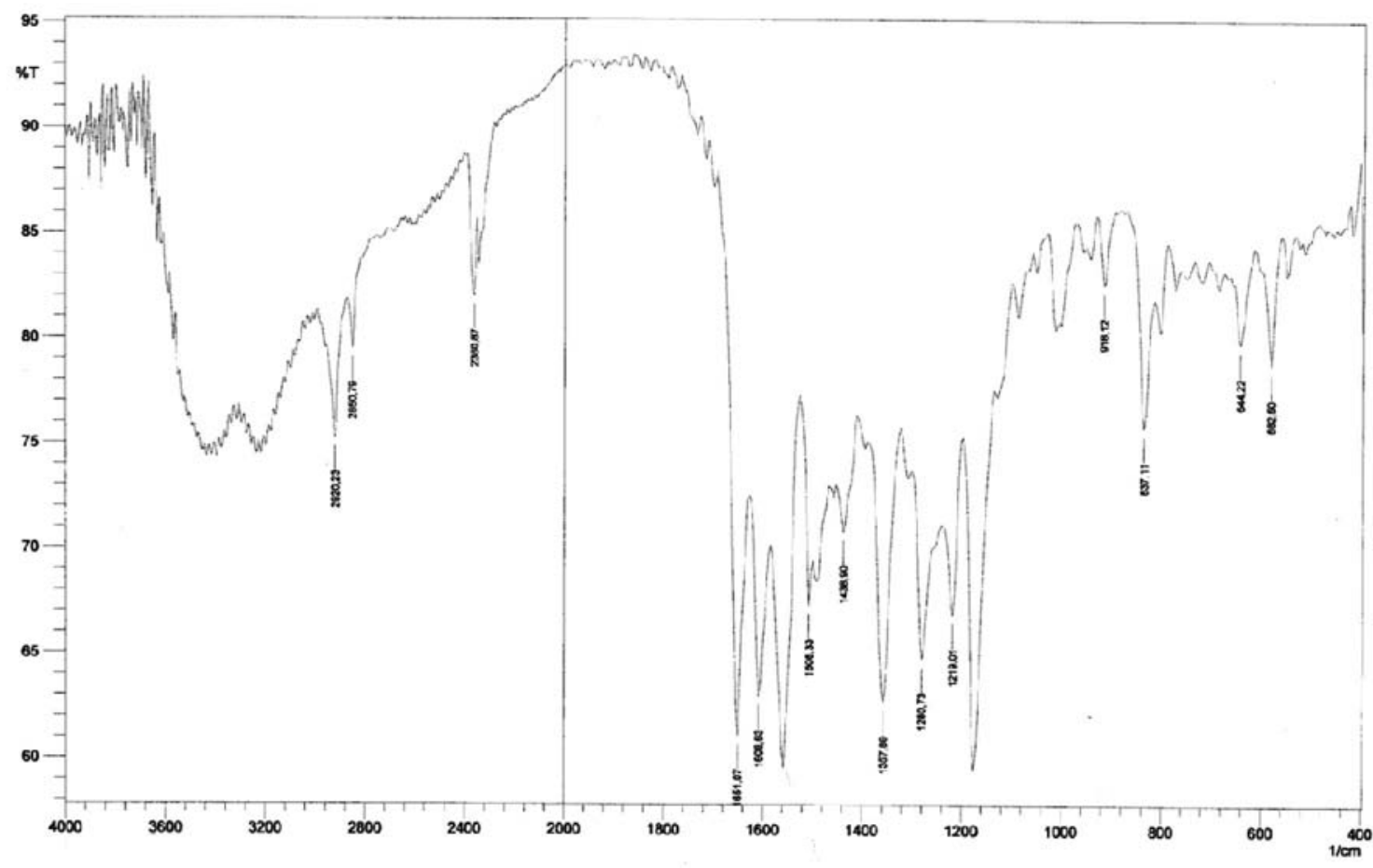

Figure S1. IR spectrum (KBr) of the compound 1 isolated of Nanuza plicata. 

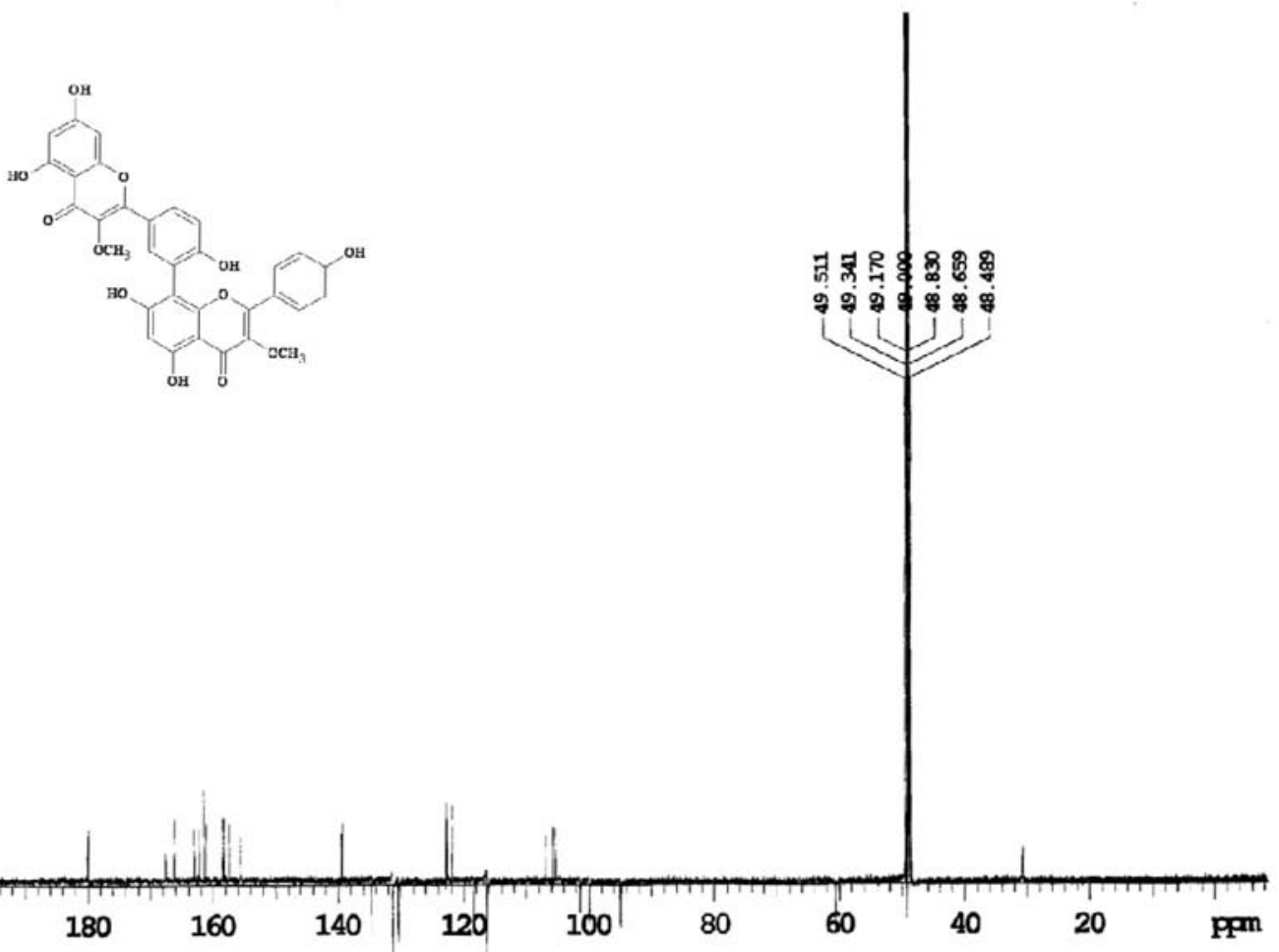

Figure S2. ${ }^{13} \mathrm{C}$ NMR spectrum $\left(\mathrm{CD}_{3} \mathrm{OD}, 125 \mathrm{MHz}\right)$ of the compound $\mathbf{1}$ isolated of Nanuza plicata.

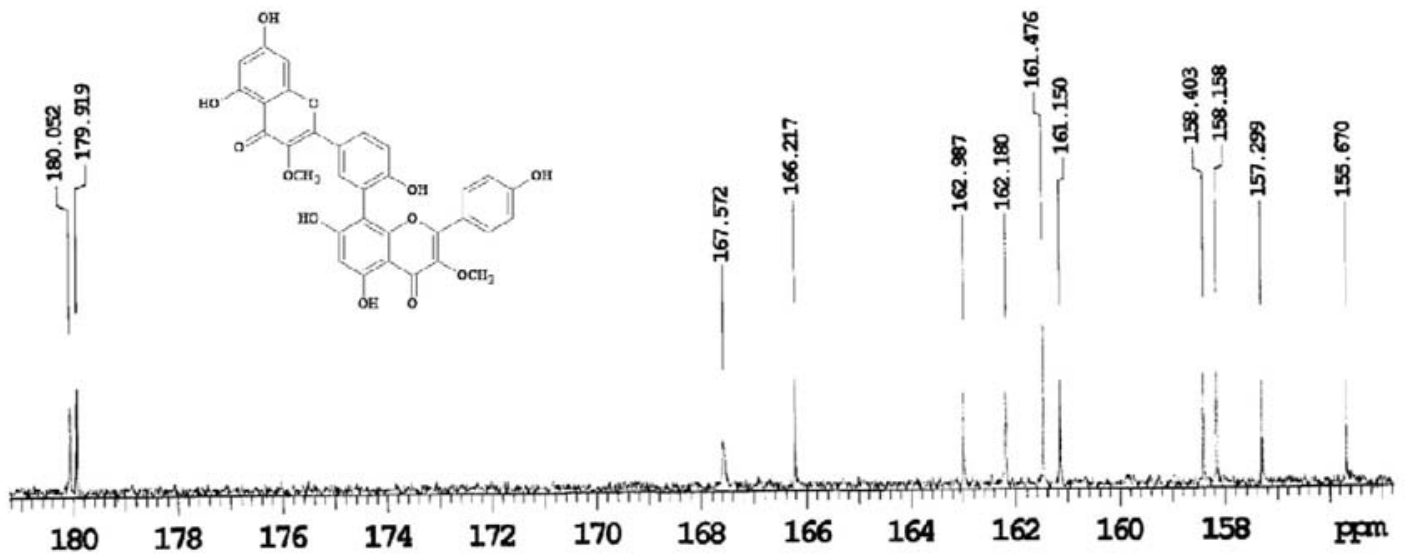

Figure S3. ${ }^{13} \mathrm{C}$ NMR spectrum $\left(\mathrm{CD}_{3} \mathrm{OD}, 125 \mathrm{MHz}, \delta_{\mathrm{C}} 156-180\right)$ of the compound $\mathbf{1}$ isolated of Nanuza plicata. 


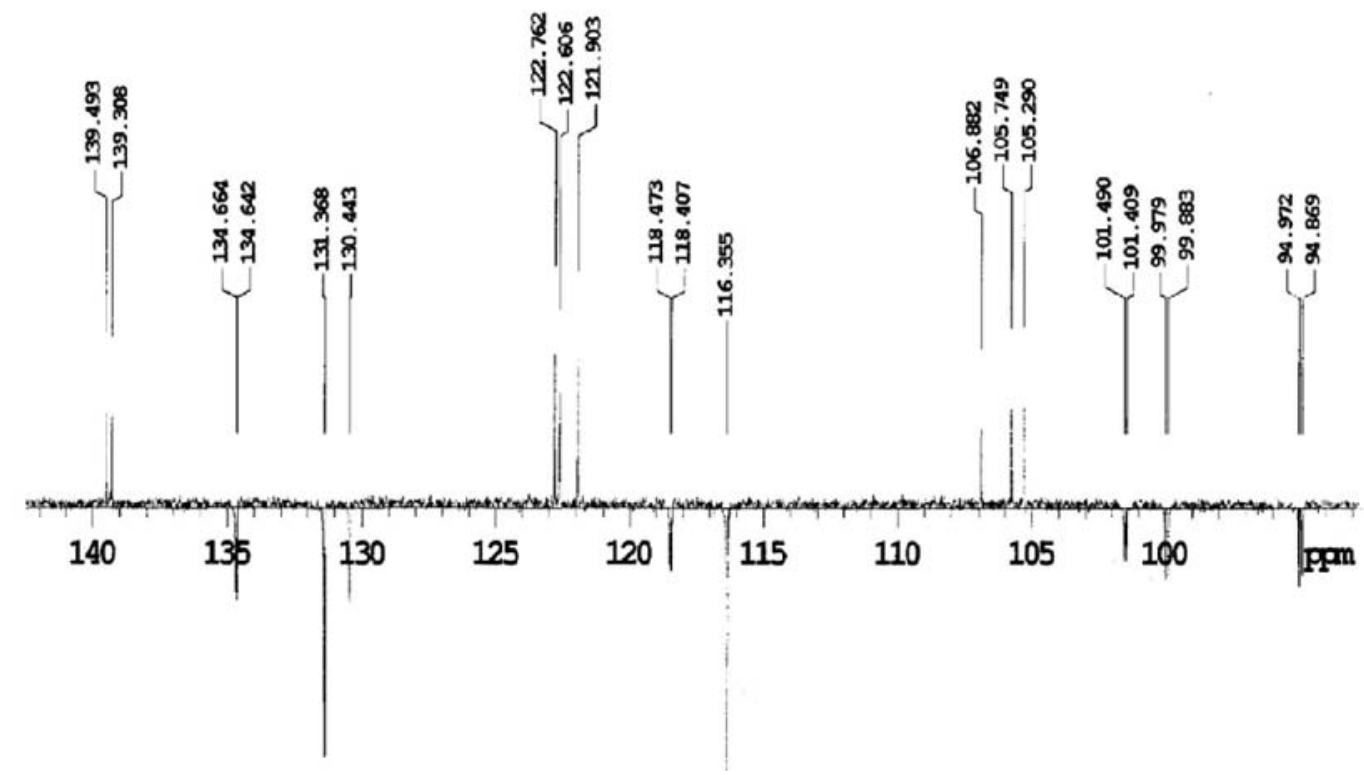

Figure S4. ${ }^{13} \mathrm{C}$ NMR spectrum $\left(\mathrm{CD}_{3} \mathrm{OD}, 125 \mathrm{MHz}, \delta_{\mathrm{C}}\right.$ 94-139) of the compound 1 isolated of Nanuza plicata.

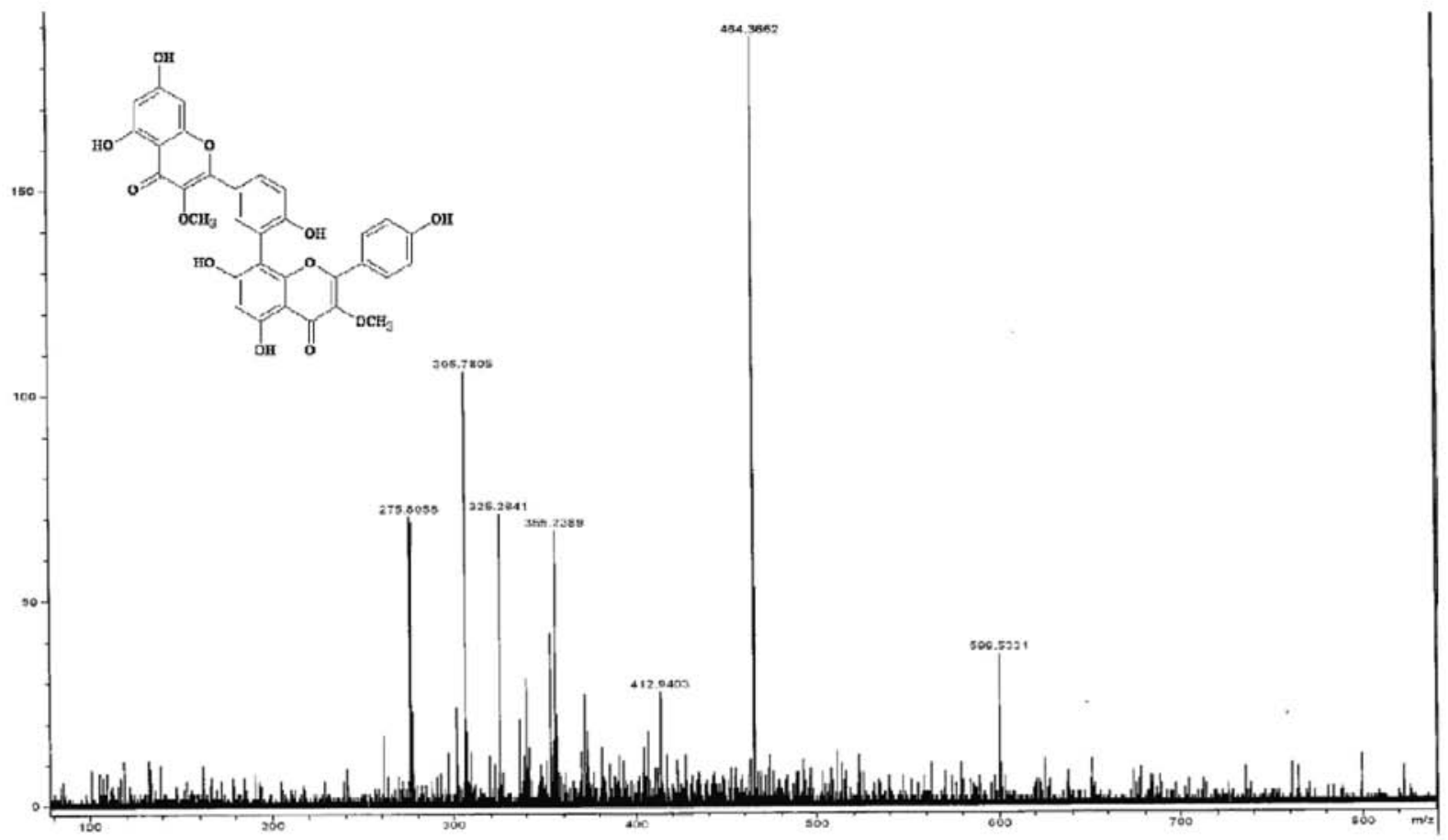

Figure S5. HR-ESI-MS spectrum of the compound 1 isolated of Nanuza plicata. 


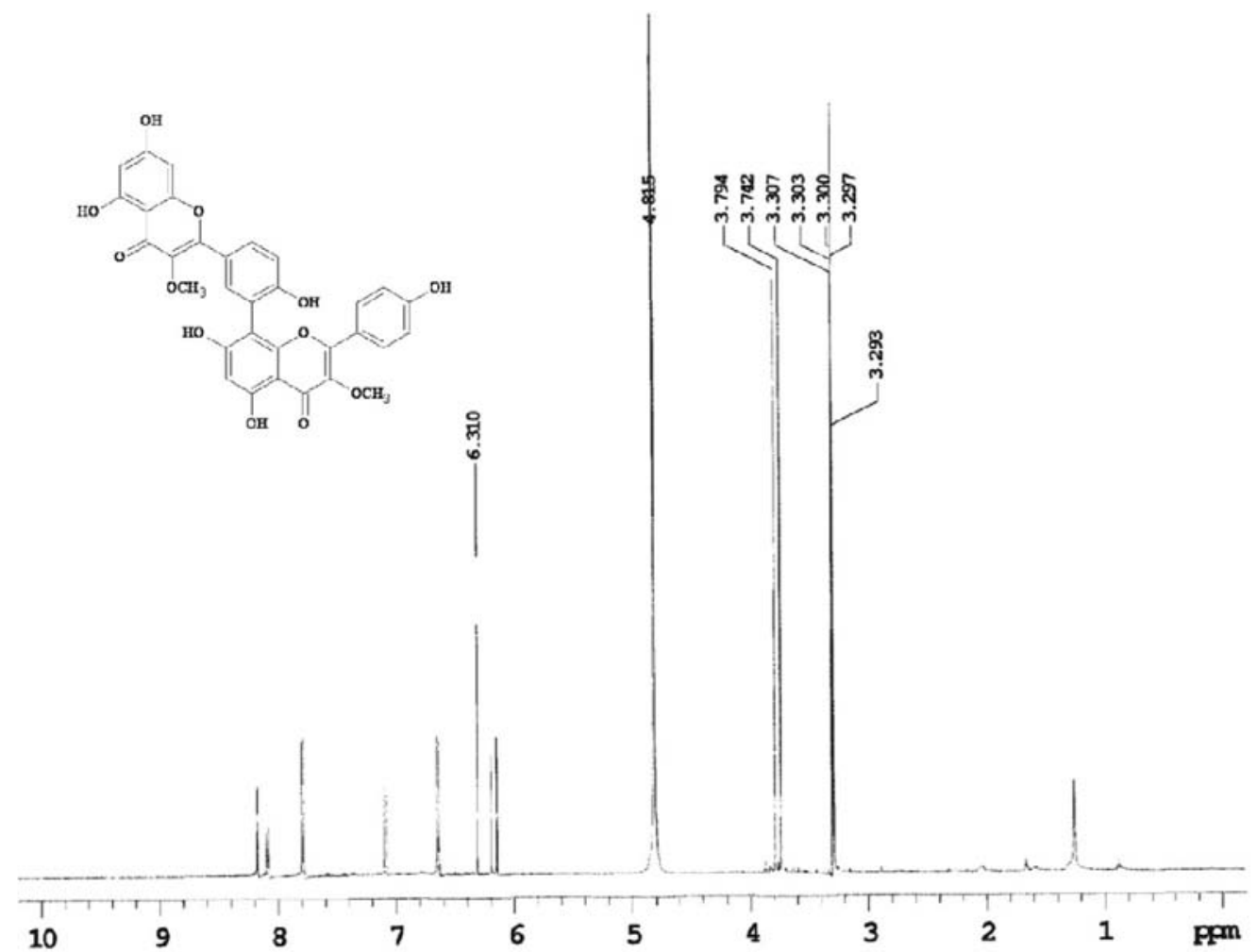

Figure S6. ${ }^{1} \mathrm{H}$ NMR spectrum $\left(\mathrm{CD}_{3} \mathrm{OD}, 500 \mathrm{MHz}\right)$ of the compound $\mathbf{1}$ isolated of Nanuza plicata.

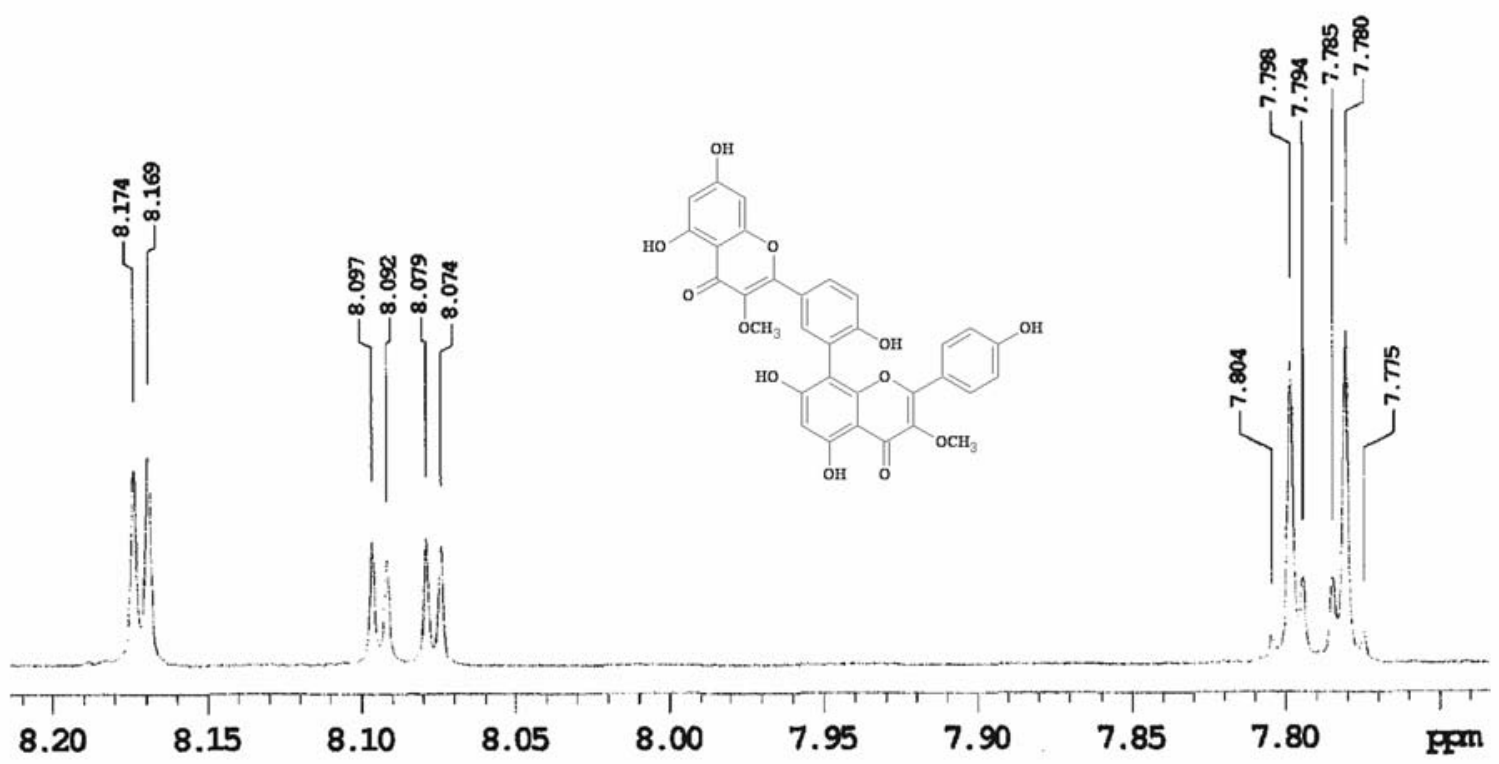

Figure S7. ${ }^{1} \mathrm{H}$ NMR spectrum $\left(\mathrm{CD}_{3} \mathrm{OD}, 500 \mathrm{MHz}, \delta_{\mathrm{H}}\right.$ 7.8-8.2) of the compound 1 isolated of Nanuza plicata. 


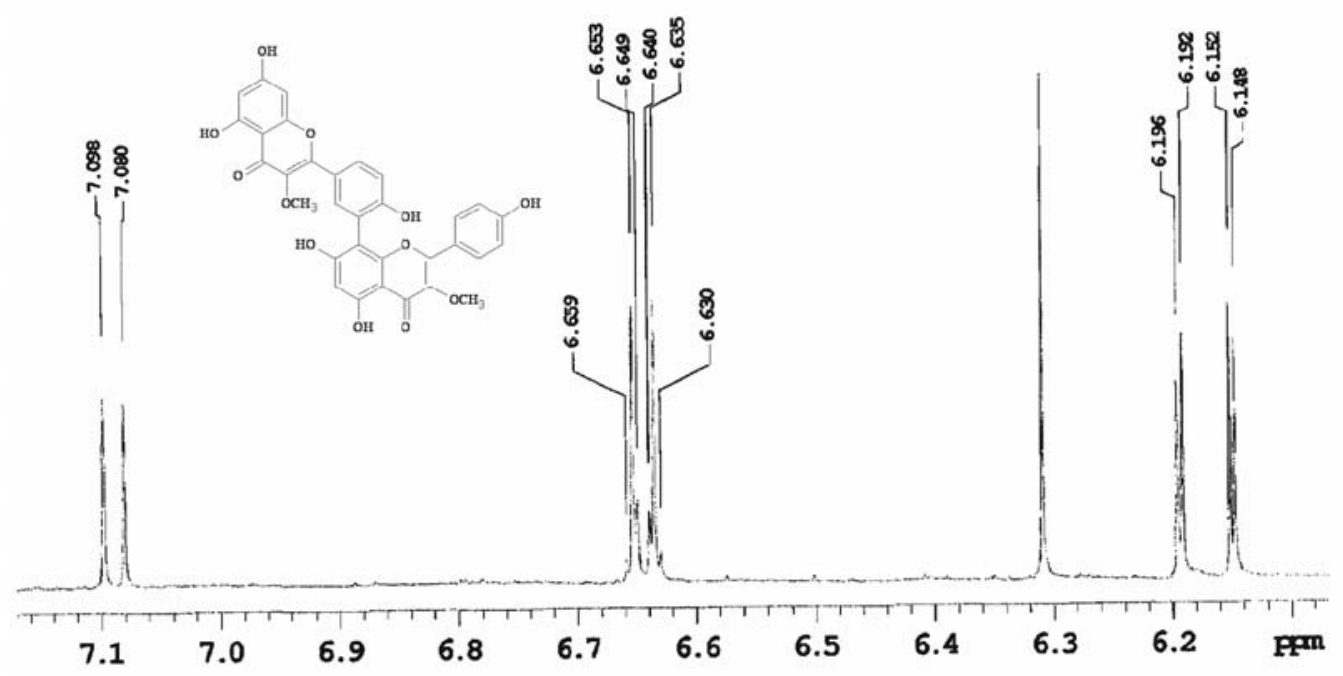

Figure S8. ${ }^{1} \mathrm{H}$ NMR spectrum $\left(\mathrm{CD}_{3} \mathrm{OD}, 500 \mathrm{MHz}, \delta_{\mathrm{H}} 6.1-7.1\right)$ of the compound 1 isolated of Nanuza plicata.

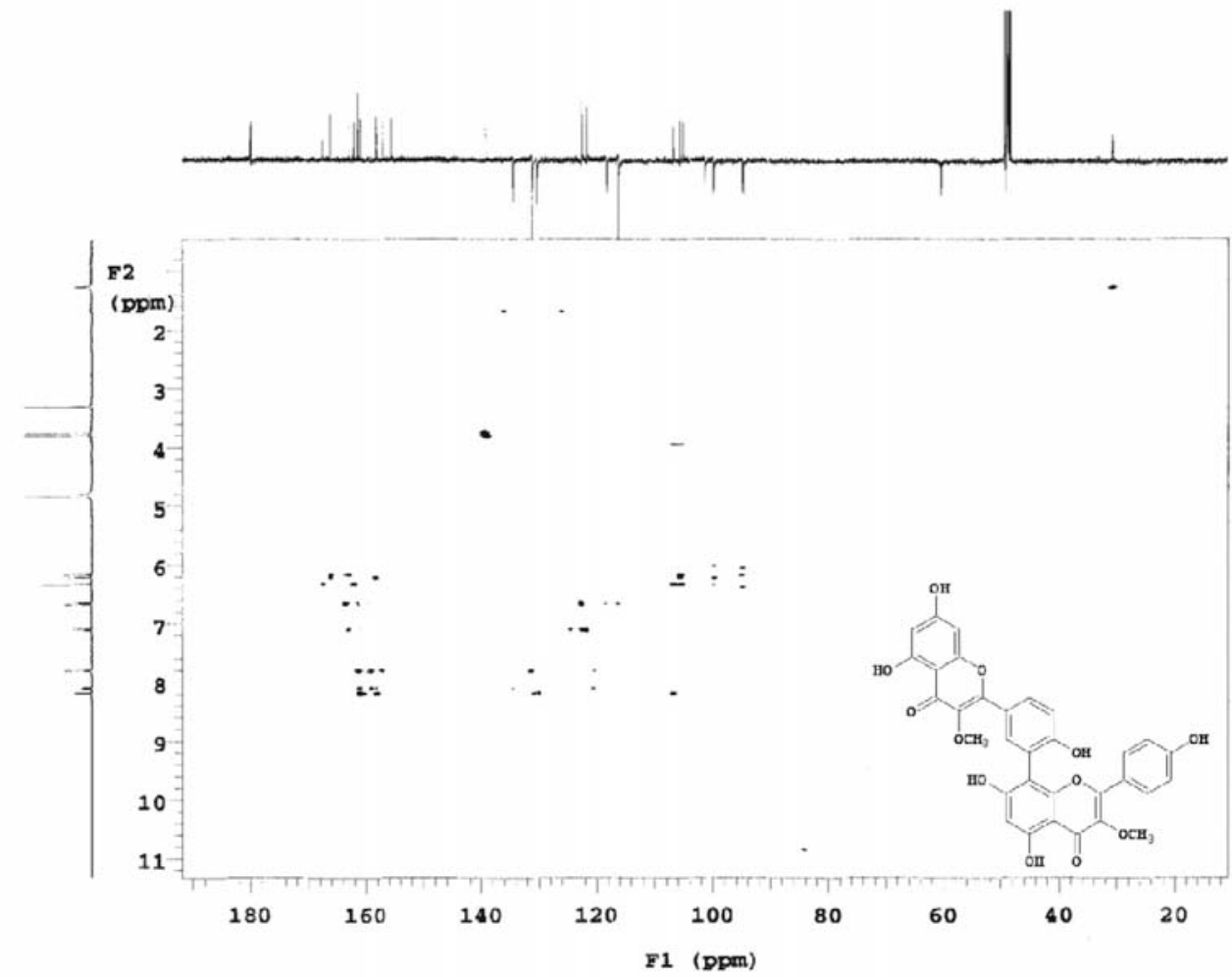

Figure S9. HSQC NMR experiment $\left(\mathrm{CD}_{3} \mathrm{OD}, 500 \times 125 \mathrm{MHz}\right)$ of the compound $\mathbf{1}$ isolated of Nanuza plicata. 

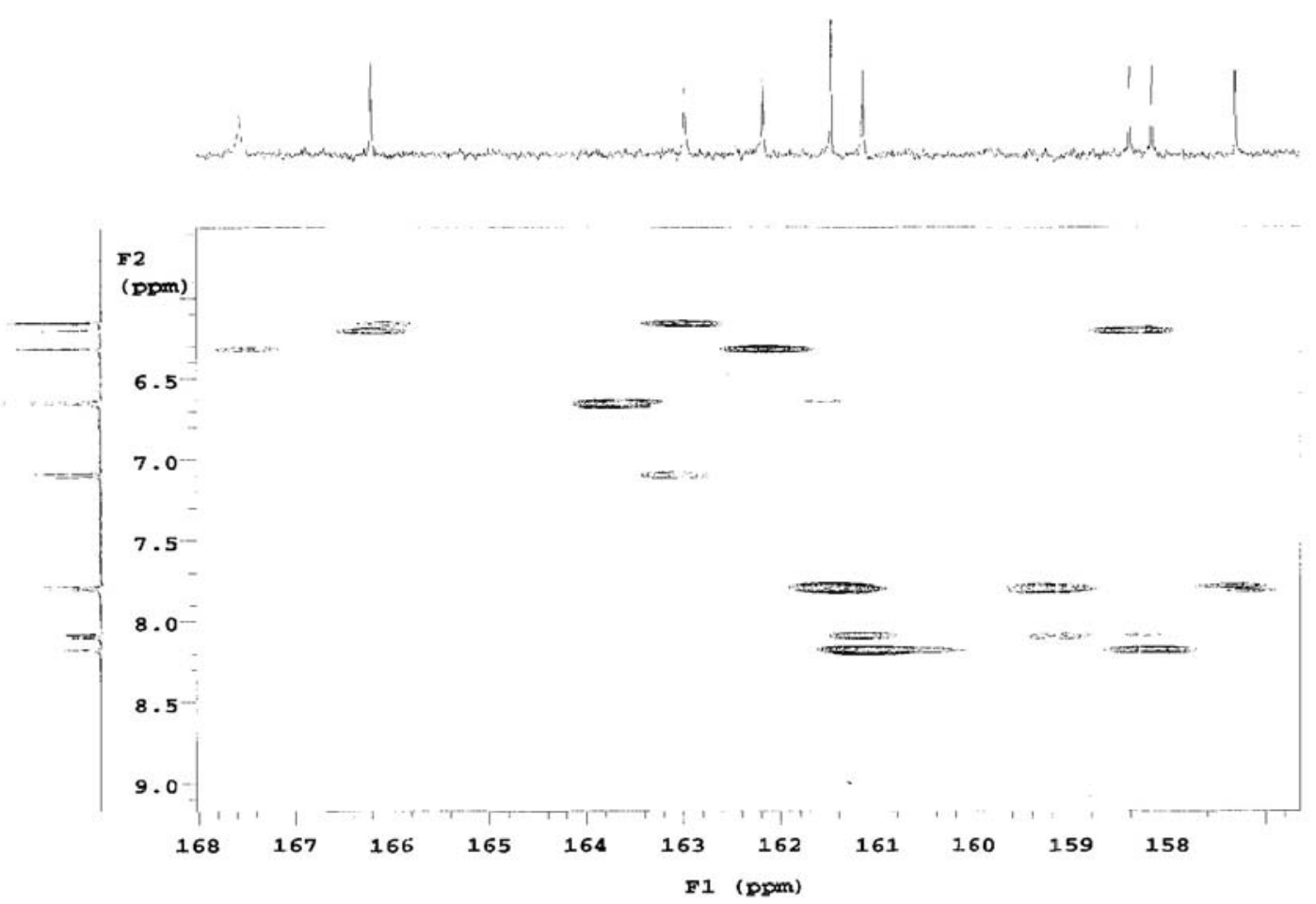

Figure S10. HMBC NMR experiment $\left(\mathrm{CD}_{3} \mathrm{OD}, 500 \times 125 \mathrm{MHz}, \delta_{\mathrm{C}} 158-168\right)$ of the compound 1 isolated of Nanuza plicata.

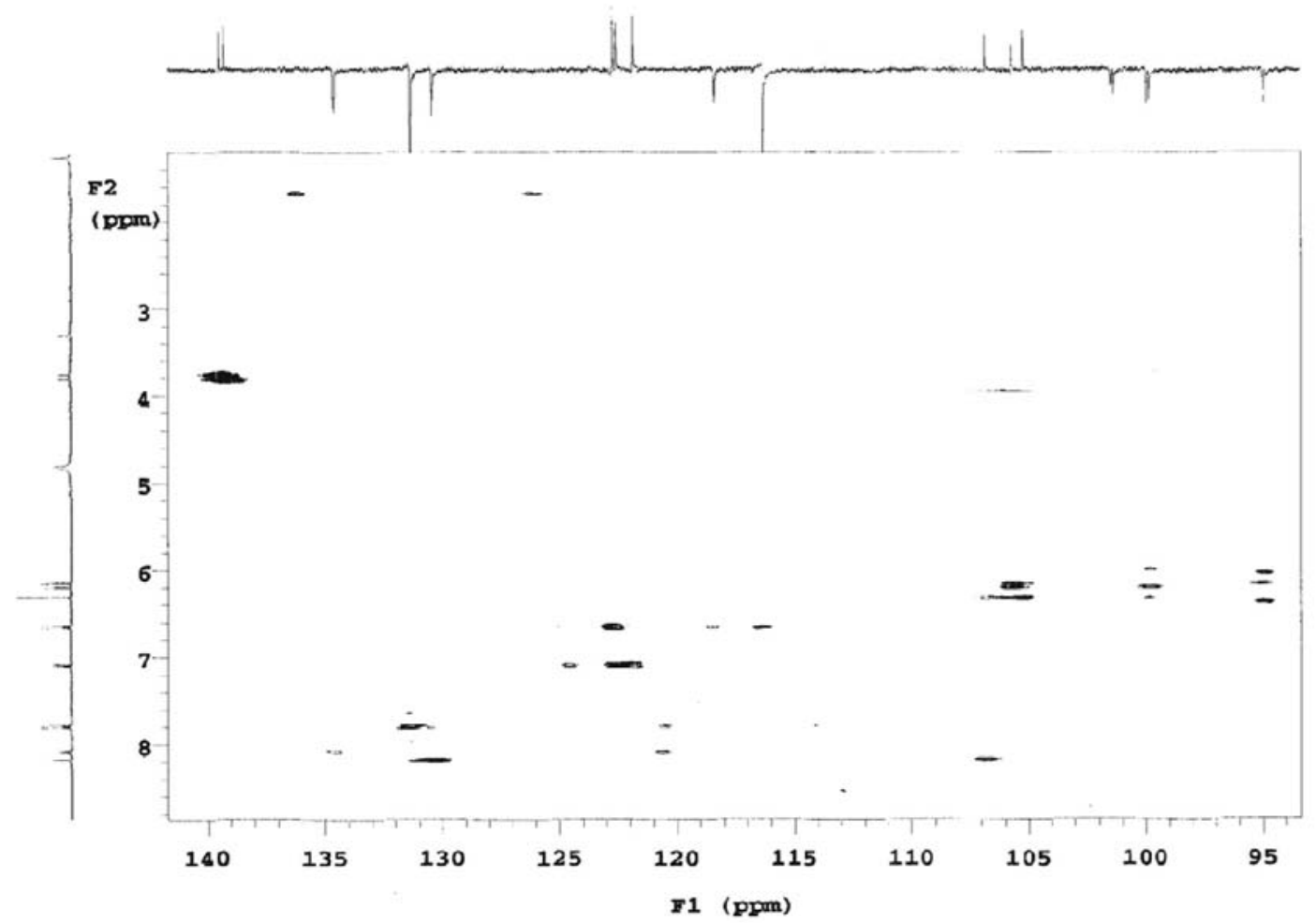

Figure S11. HMBC NMR experiment $\left(\mathrm{CD}_{3} \mathrm{OD}, 500 \times 125 \mathrm{MHz}, \delta_{\mathrm{C}} 95-140\right)$ of the compound 1 isolated of Nanuza plicata. 


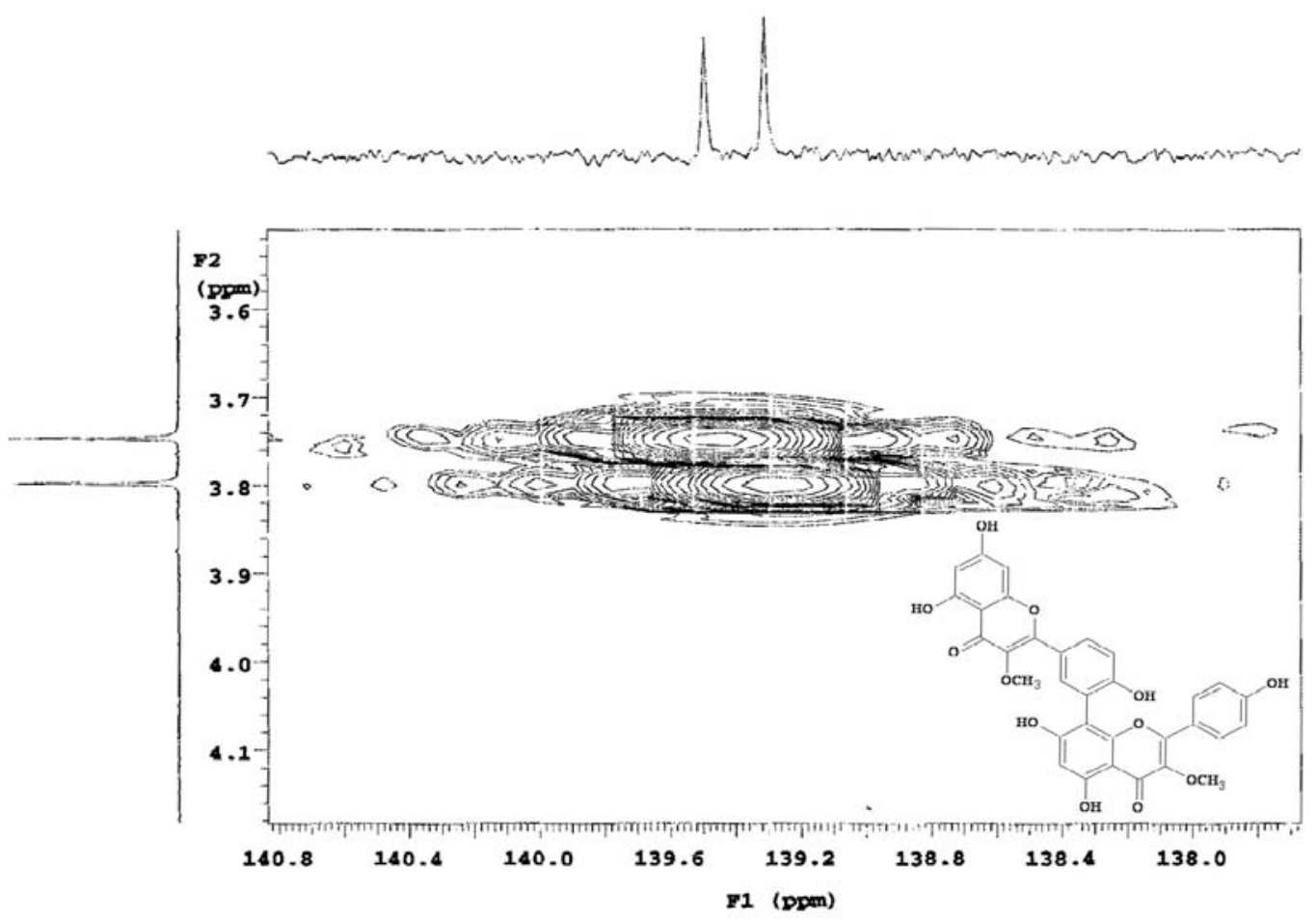

Figure S12. HMBC NMR experiment ( $\left.\mathrm{CD}_{3} \mathrm{OD}, 500 \times 125 \mathrm{MHz}, \delta_{\mathrm{C}} 138-140\right)$ of the compound 1 isolated of Nanuza plicata.

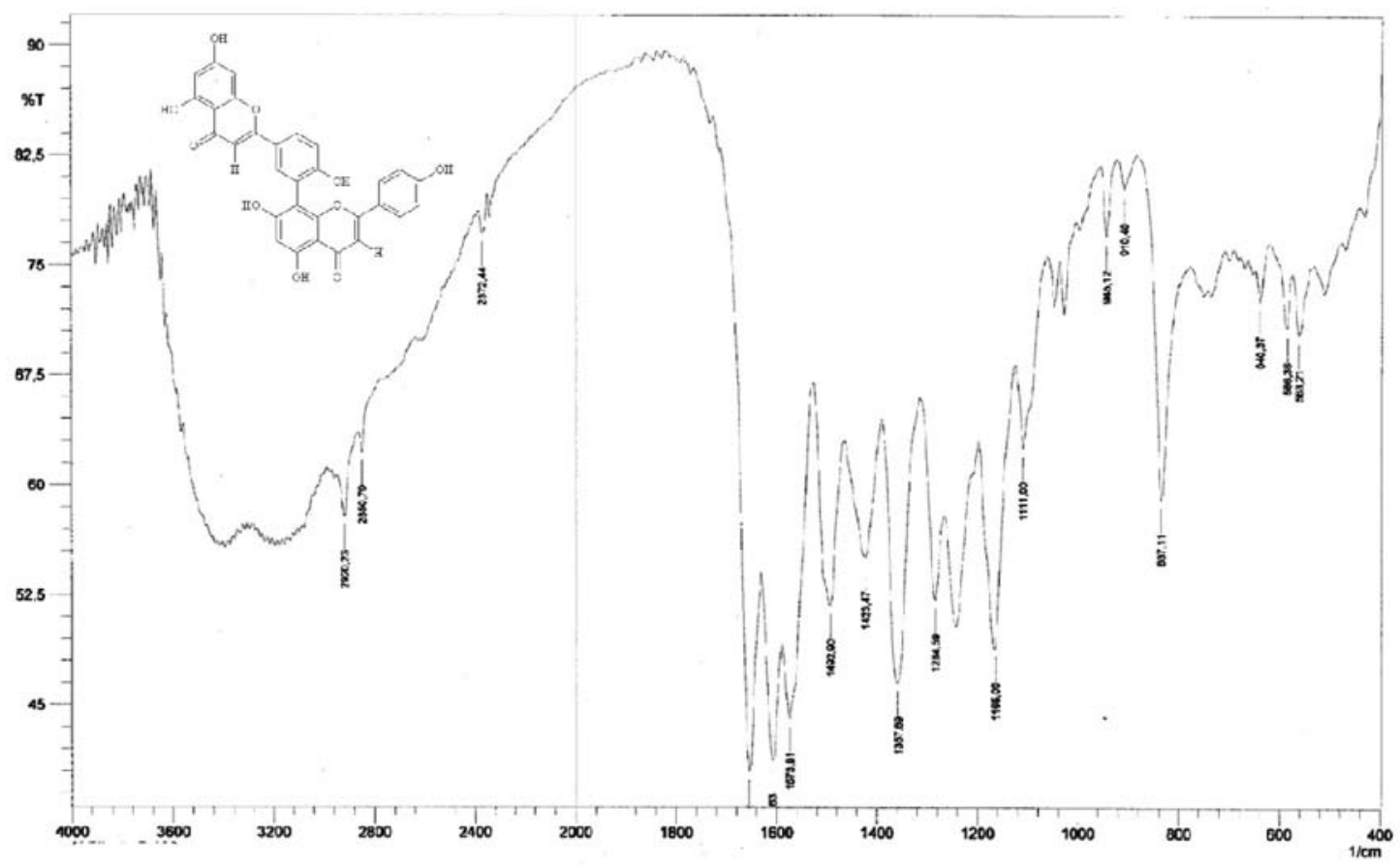

Figure S13. IR spectrum (KBr) of the compound 2 isolated of Nanuza plicata. 


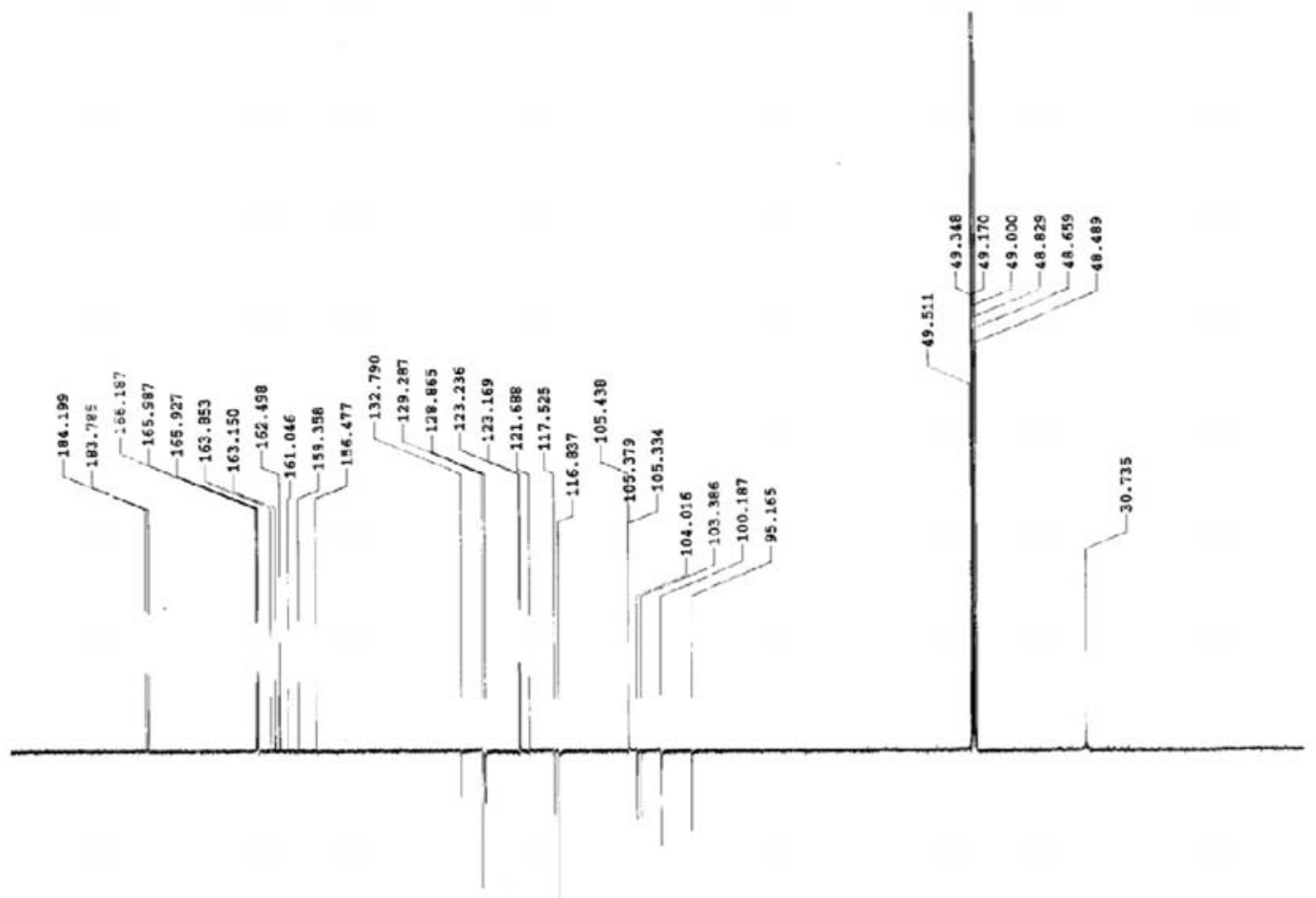

Figure S14. ${ }^{13} \mathrm{C}$ NMR spectrum $\left(\mathrm{CD}_{3} \mathrm{OD}, 125 \mathrm{MHz}\right)$ of the compound 2 isolated of Nanuza plicata.
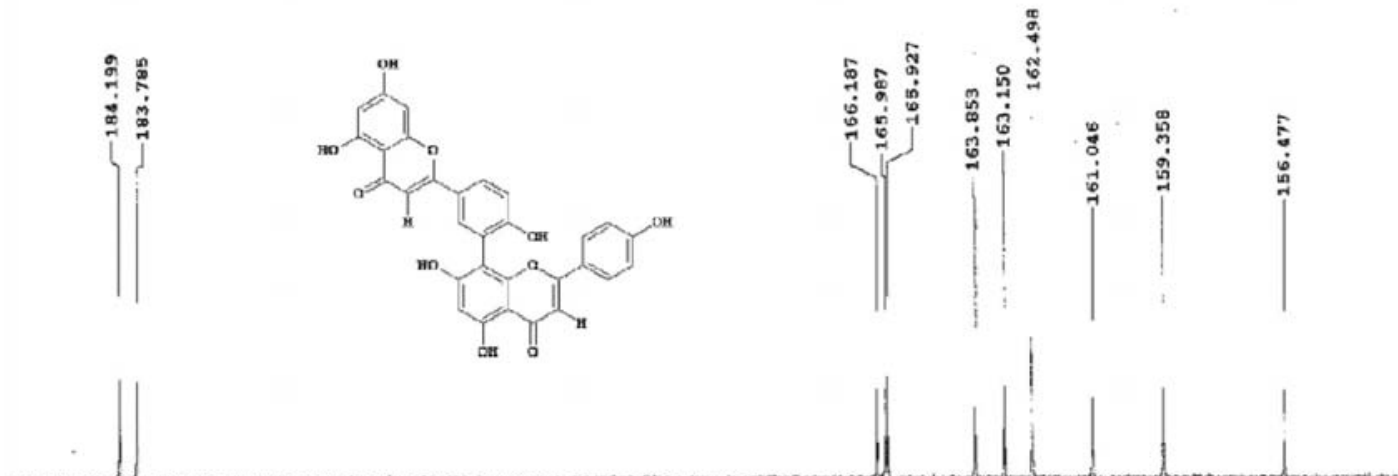

Figure S15. ${ }^{13} \mathrm{C}$ NMR spectrum $\left(\mathrm{CD}_{3} \mathrm{OD}, 125 \mathrm{MHz}\right)$ of the compound 2 isolated of Nanuza plicata. 


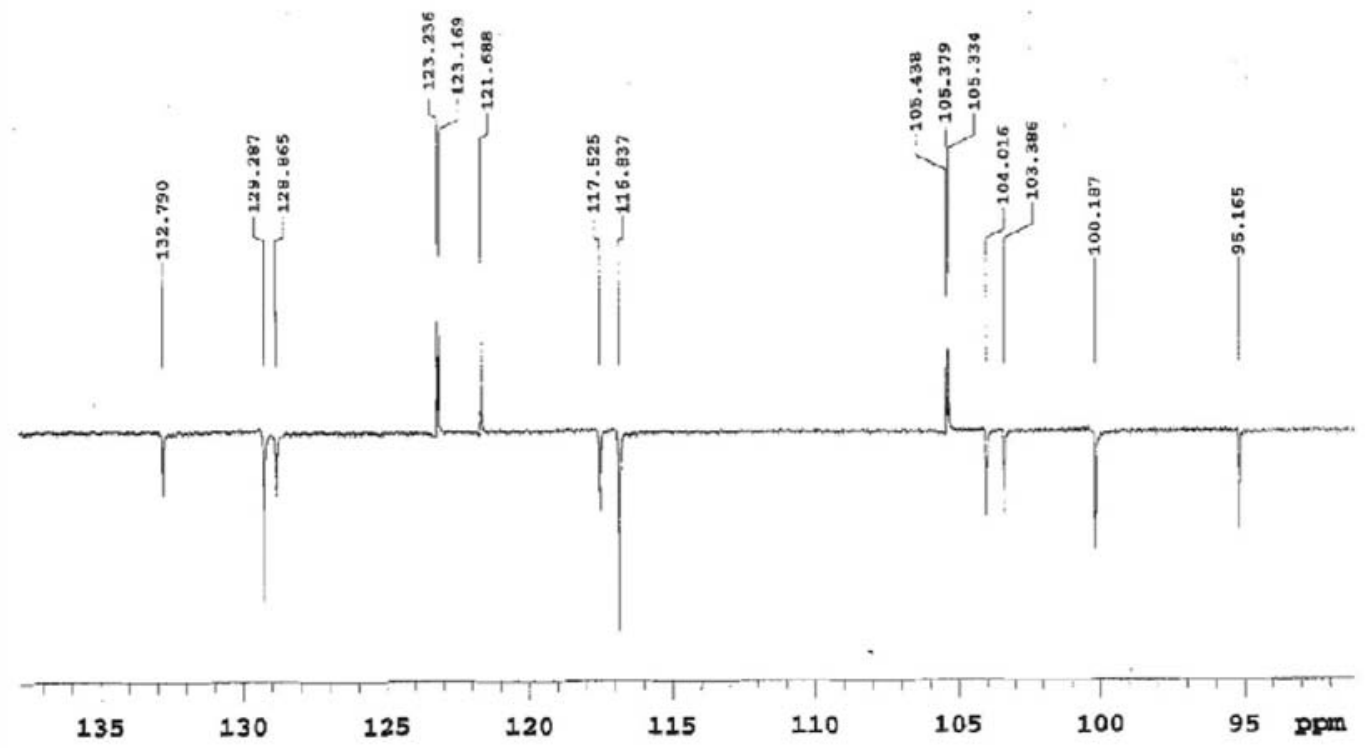

Figure S16. ${ }^{13} \mathrm{C}$ NMR spectrum $\left(\mathrm{CD}_{3} \mathrm{OD}, 125 \mathrm{MHz}, \delta_{\mathrm{C}}\right.$ 95-135) of the compound 2 isolated of Nanuza plicata.

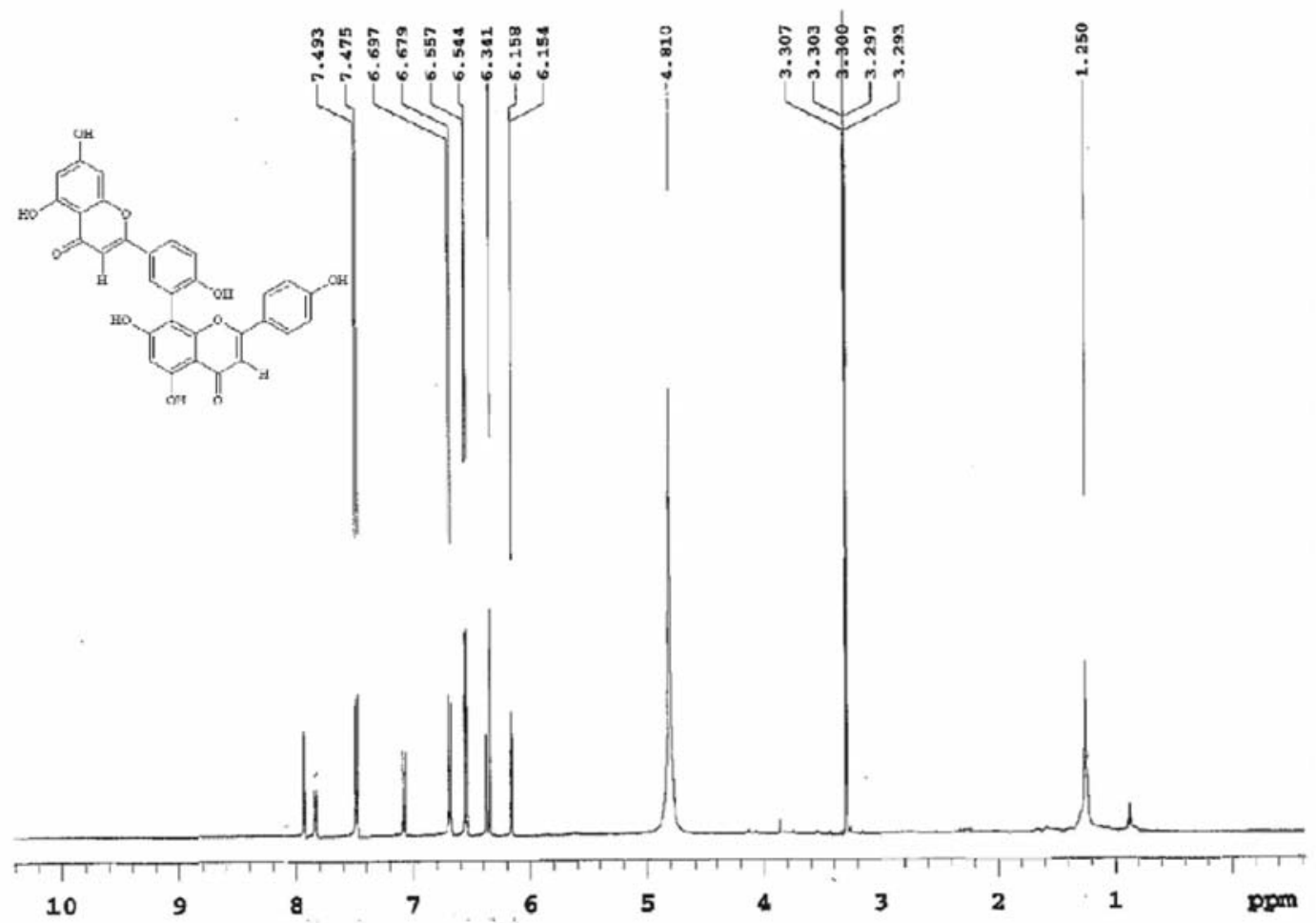

Figure S17. ${ }^{1} \mathrm{H}$ NMR spectrum $\left(\mathrm{CD}_{3} \mathrm{OD}, 500 \mathrm{MHz}\right)$ of the compound 2 isolated of Nanuza plicata. 


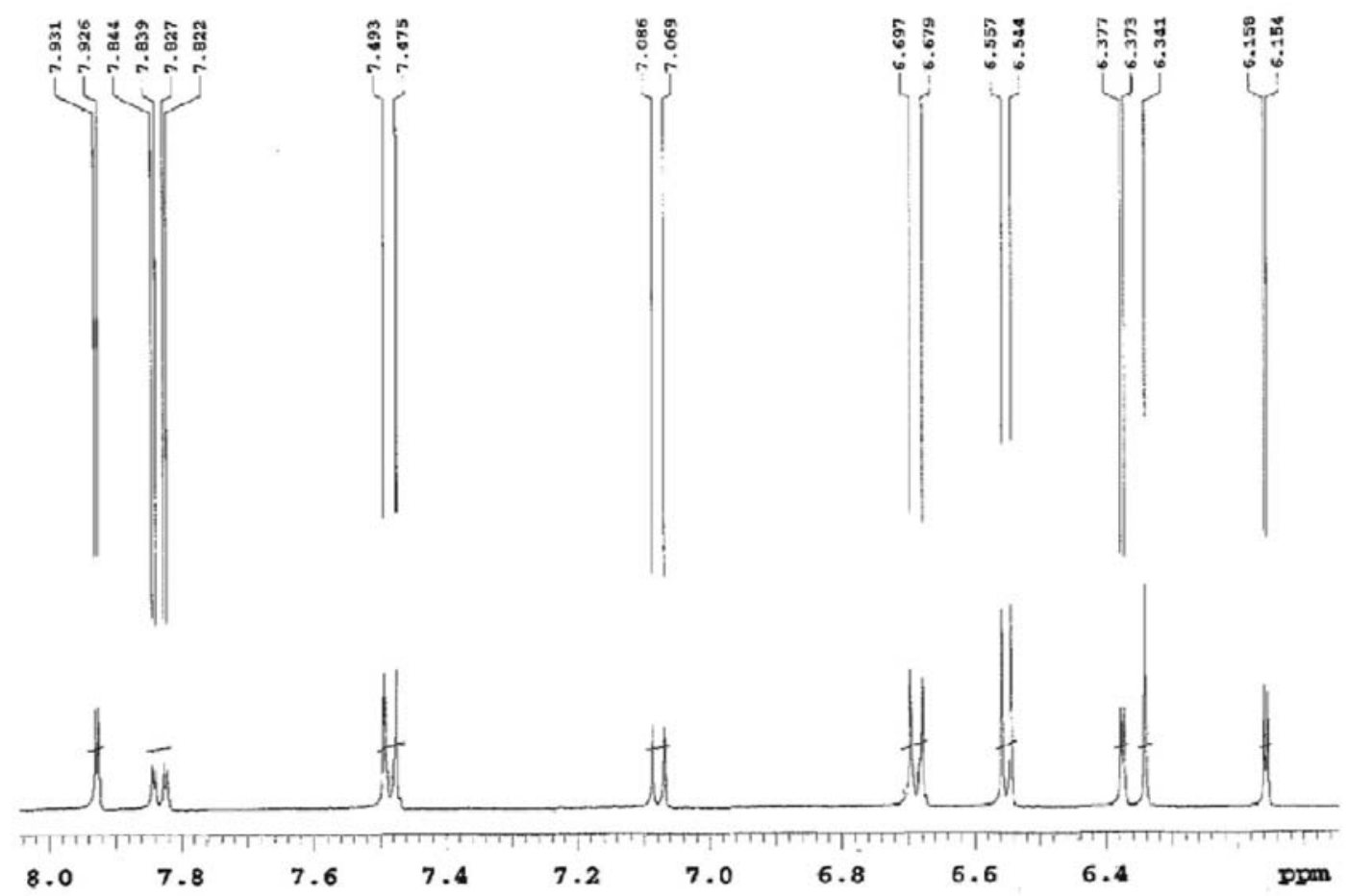

Figure S18. ${ }^{1} \mathrm{H}$ NMR spectrum $\left(\mathrm{CD}_{3} \mathrm{OD}, 500 \mathrm{MHz}, \delta_{\mathrm{H}} 6.1-7.9\right)$ of the compound 2 isolated of Nanuza plicata.

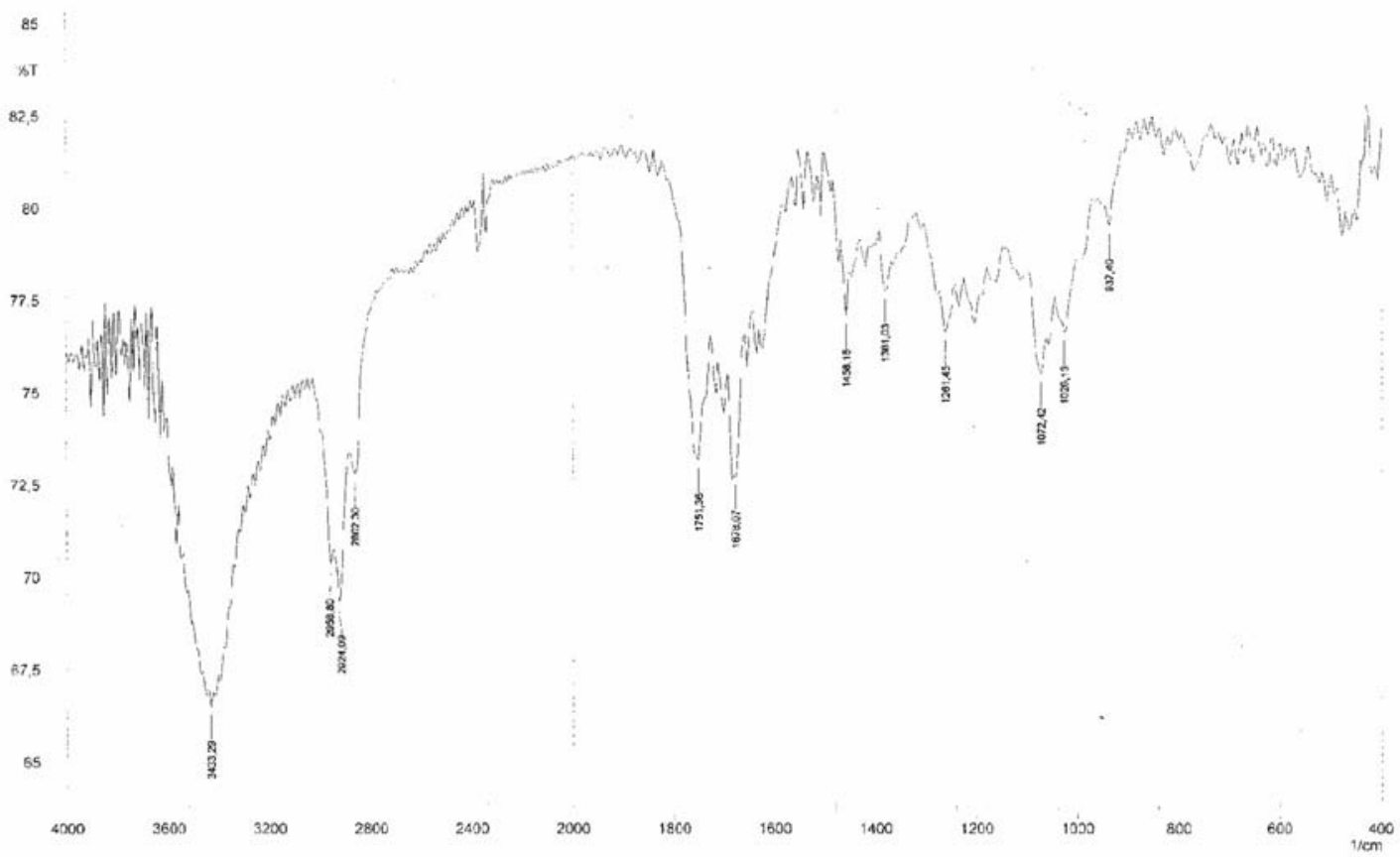

Figure S19. IR spectrum (KBr) of the compounds 3 and $\mathbf{4}$ isolated of Nanuza plicata 


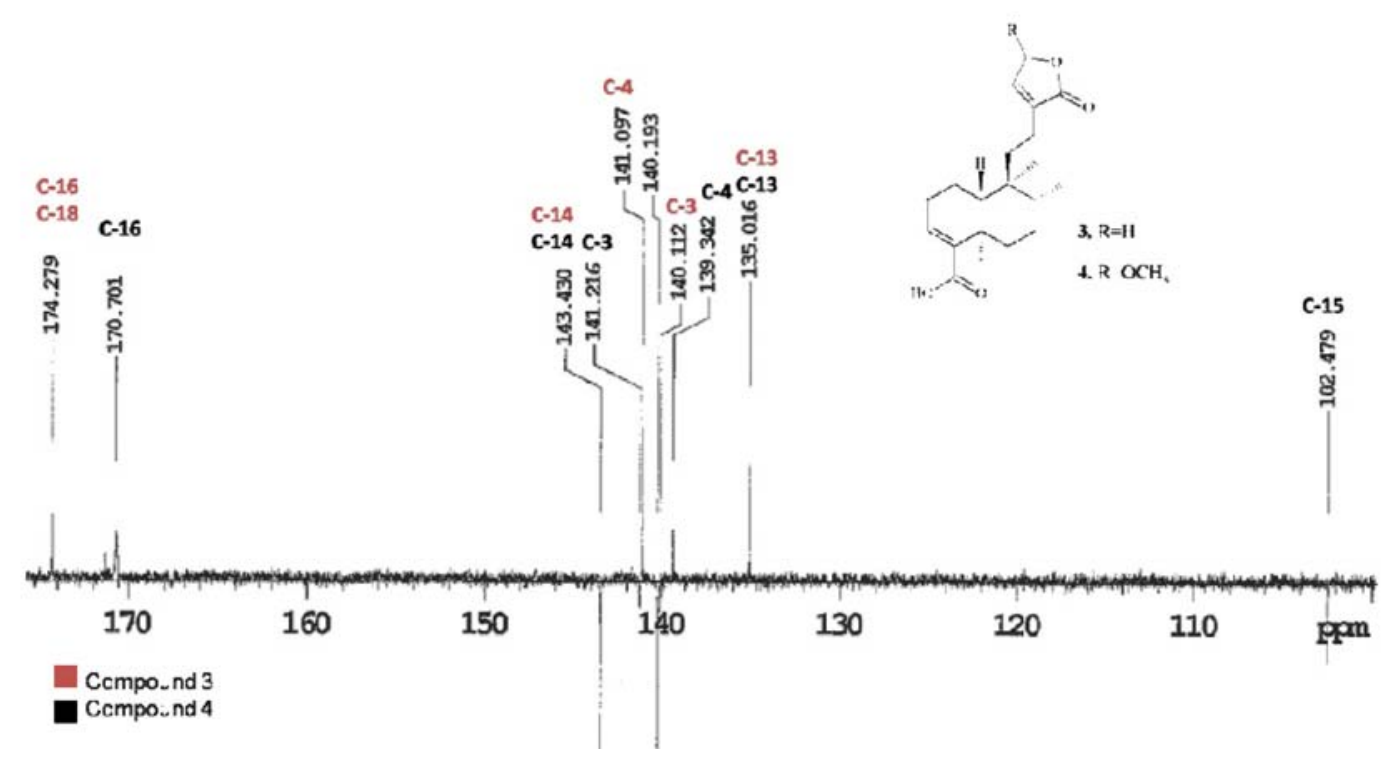

Figure S20. ${ }^{13} \mathrm{C}$ NMR spectrum $\left(\mathrm{CDCl}_{3}, 125 \mathrm{MHz} \delta_{\mathrm{C}}\right.$ 102-174) of the compounds 3 and 4 isolated of Nanuza plicata.

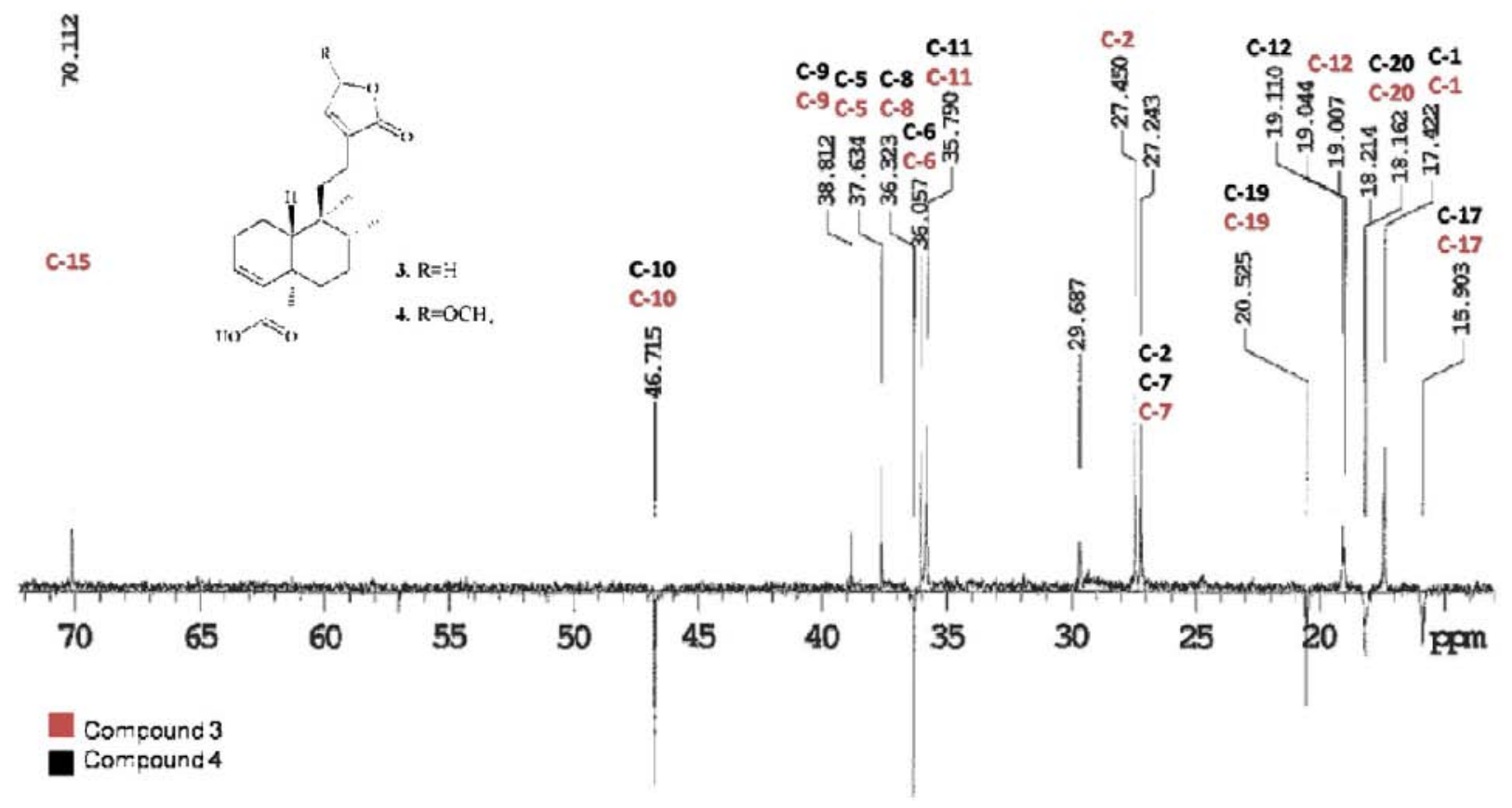

Figure S21. ${ }^{13} \mathrm{C}$ NMR spectrum $\left(\mathrm{CDCl}_{3}, 125 \mathrm{MHz} \delta_{\mathrm{C}}\right.$ 15-70) of the compounds 3 and 4 isolated of Nanuza plicata. 


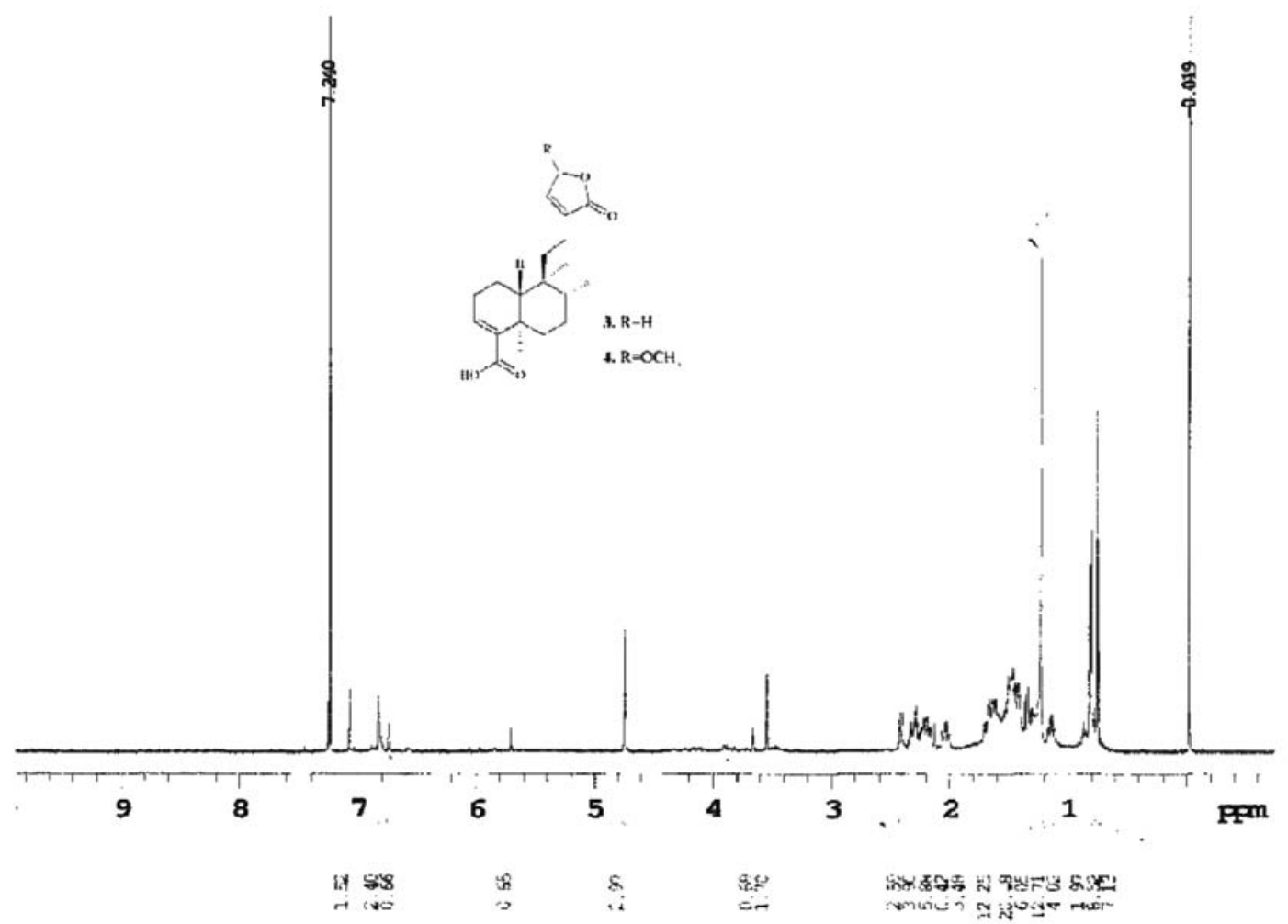

Figure S22. ${ }^{1} \mathrm{H}$ NMR spectrum $\left(\mathrm{CDCl}_{3}, 500 \mathrm{MHz}\right)$ of the compounds 3 and $\mathbf{4}$ isolated of Nanuza plicata.

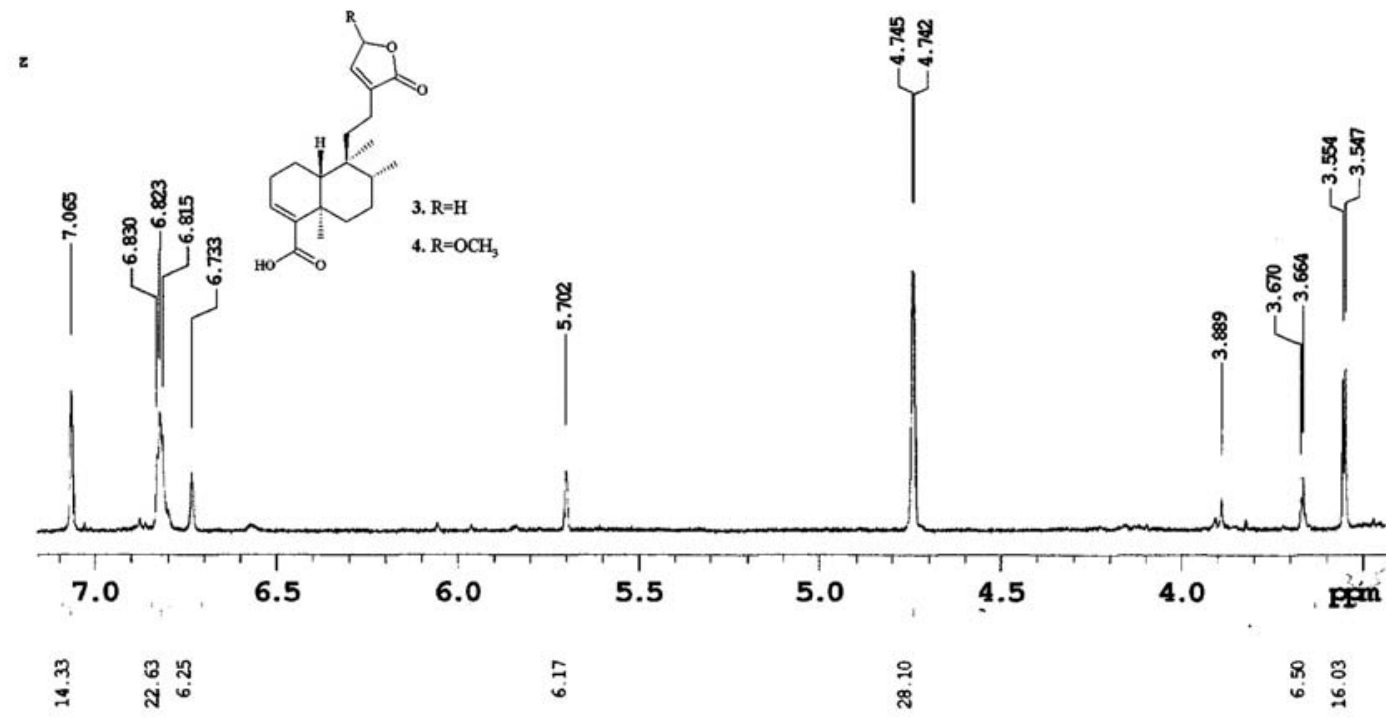

Figure S23. ${ }^{1} \mathrm{H}$ NMR spectrum $\left(\mathrm{CDCl}_{3}, 500 \mathrm{MHz}, \delta_{\mathrm{H}}\right.$ 3.5-7.0) of the compounds 3 and 4 isolated of Nanuza plicata. 


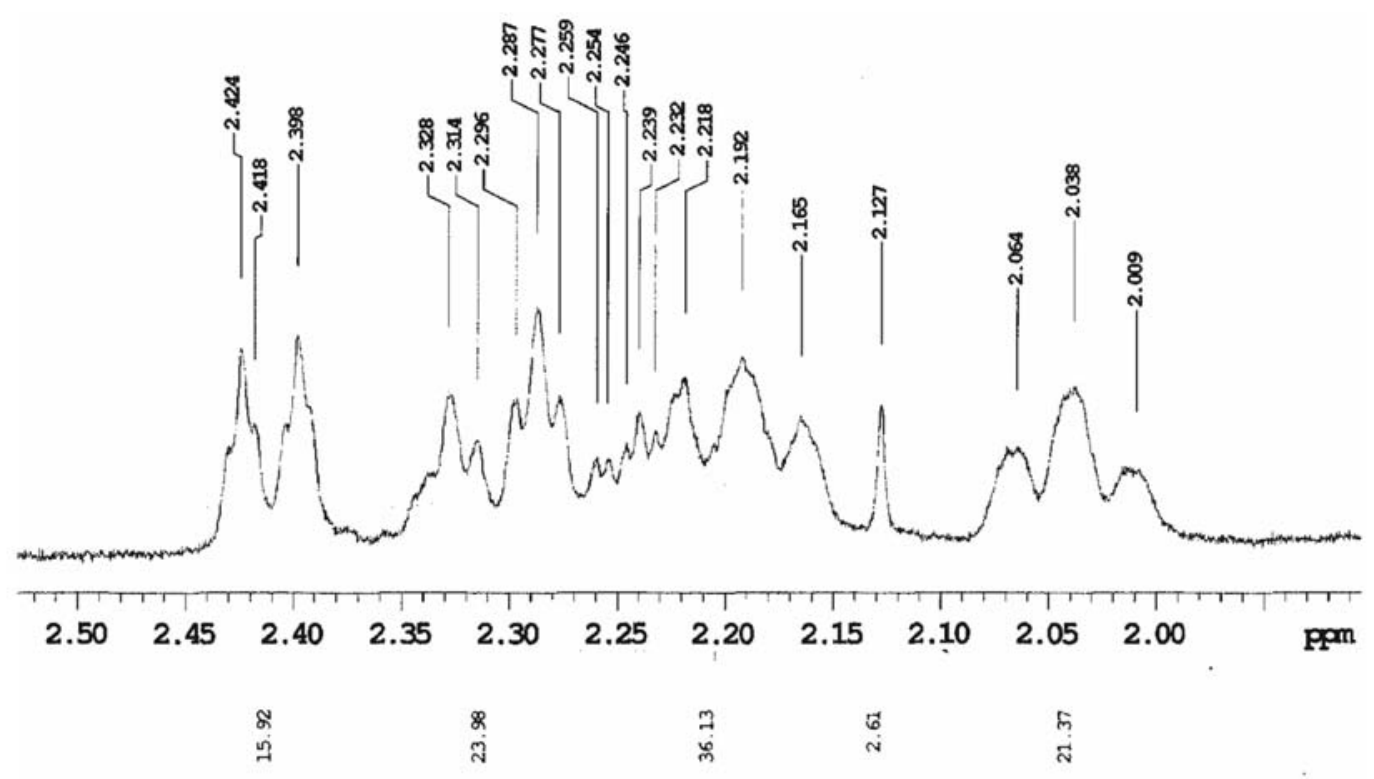

Figure S24. ${ }^{1} \mathrm{H}$ NMR spectrum $\left(\mathrm{CDCl}_{3}, 500 \mathrm{MHz}, \delta_{\mathrm{H}} 2.0-2.4\right)$ of the compounds 3 and 4 isolated of Nanuza plicata.

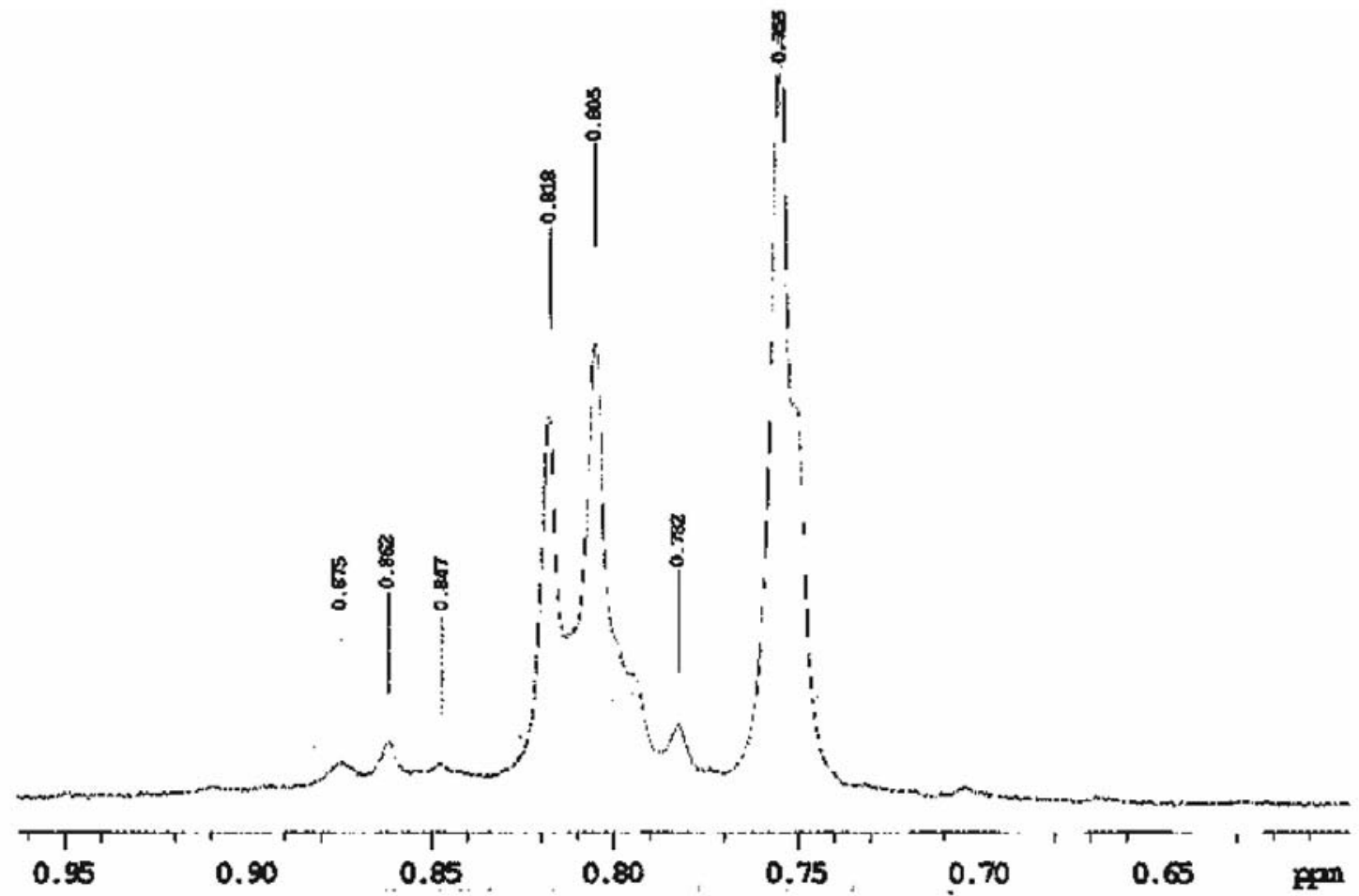

Figure S25. ${ }^{1} \mathrm{H}$ NMR spectrum $\left(\mathrm{CDCl}_{3}, 500 \mathrm{MHz}, \delta_{\mathrm{H}} 0.65-0.95\right)$ of the compounds $\mathbf{3}$ and $\mathbf{4}$ isolated of Nanuza plicata. 


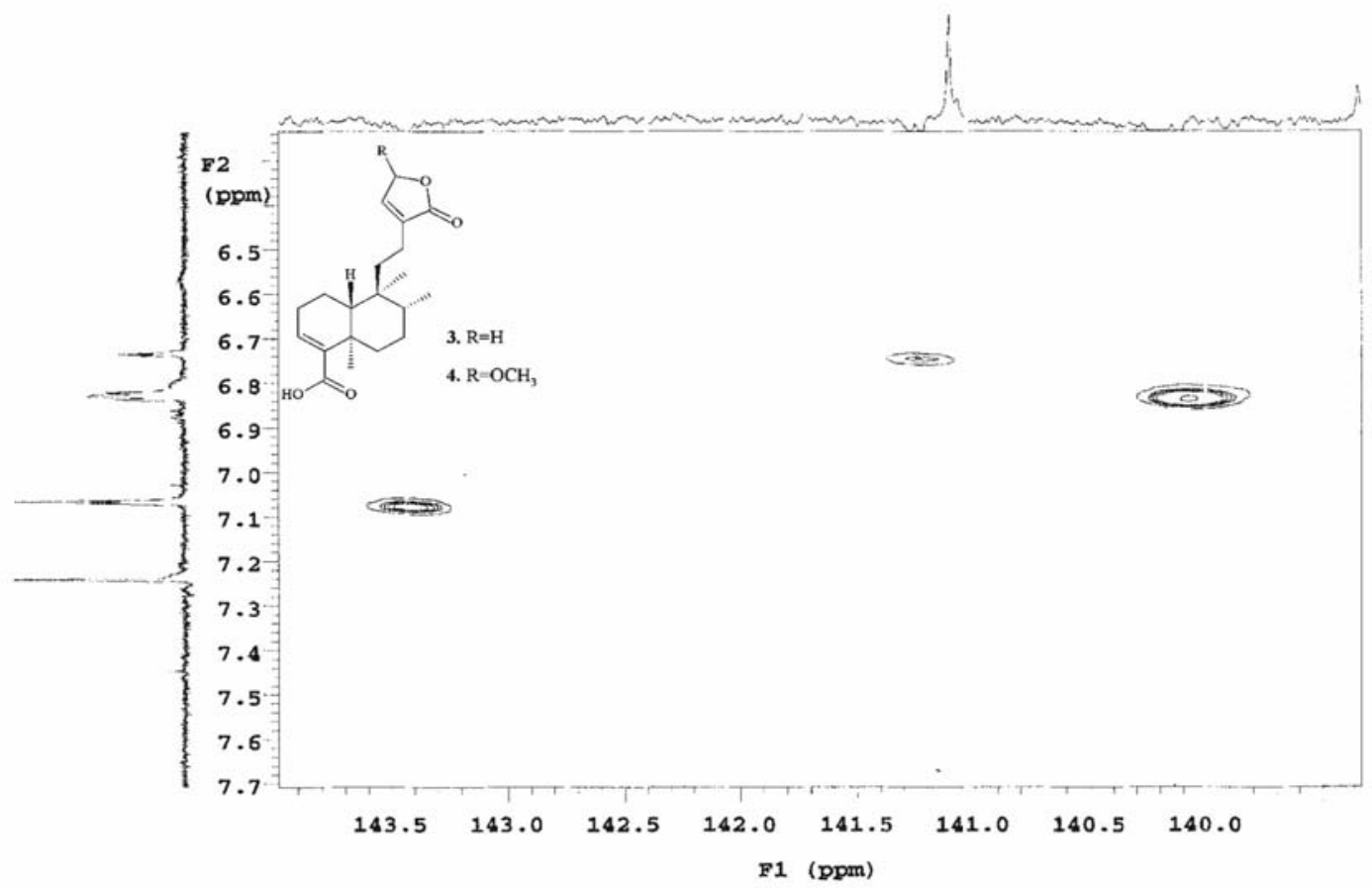

Figure S26. HMQC NMR experiment $\left(\mathrm{CDCl}_{3}, 500 \times 125 \mathrm{MHz}, \delta_{\mathrm{C}} 140-144\right)$ of the compounds 3 and 4 isolated of Nanuza plicata.

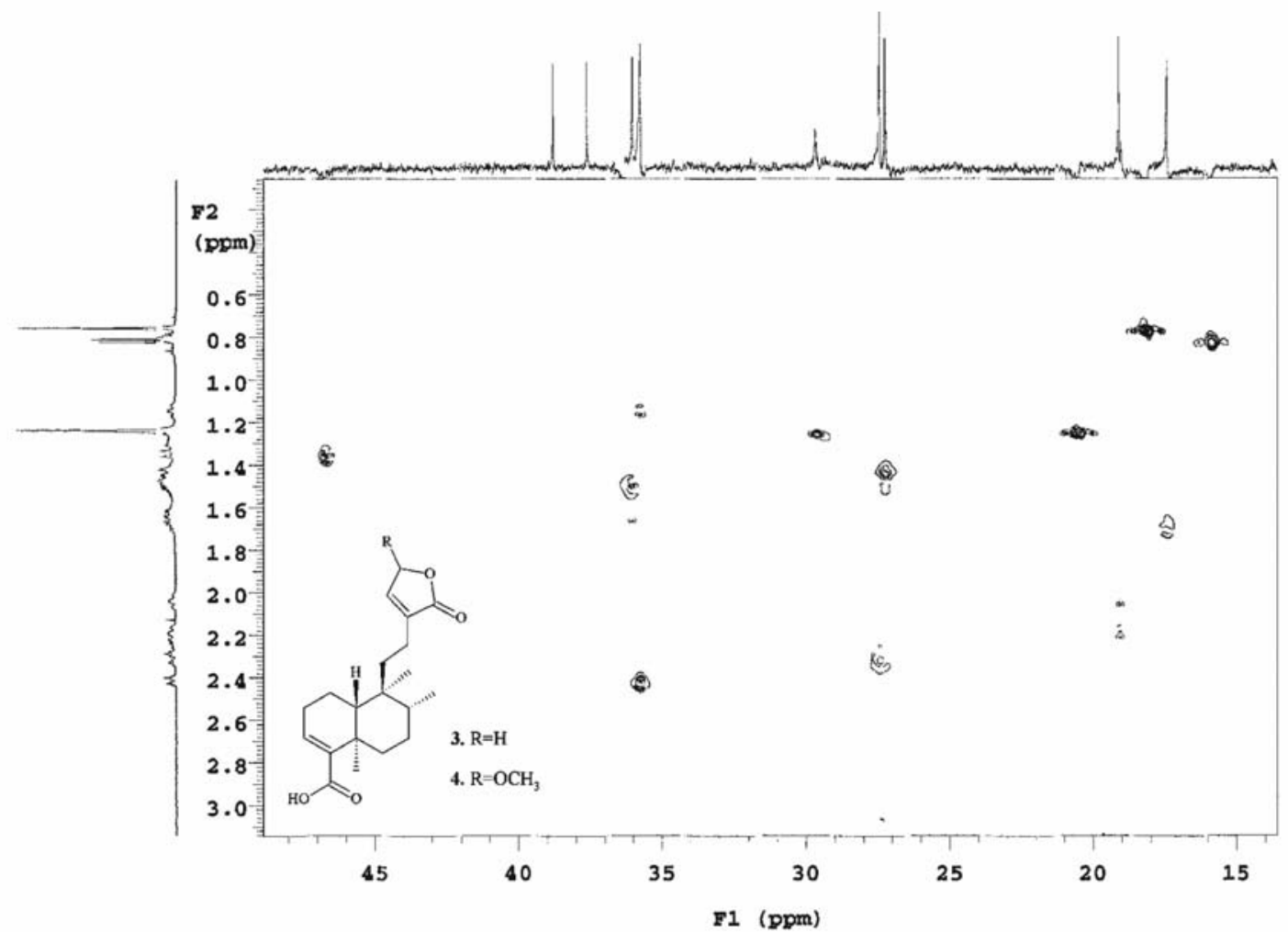

Figure S27. HMQC NMR experiment $\left(\mathrm{CDCl}_{3}, 500 \times 125 \mathrm{MHz}, \delta_{\mathrm{C}} 15-45\right)$ of the compounds 3 and 4 isolated of Nanuza plicata. 


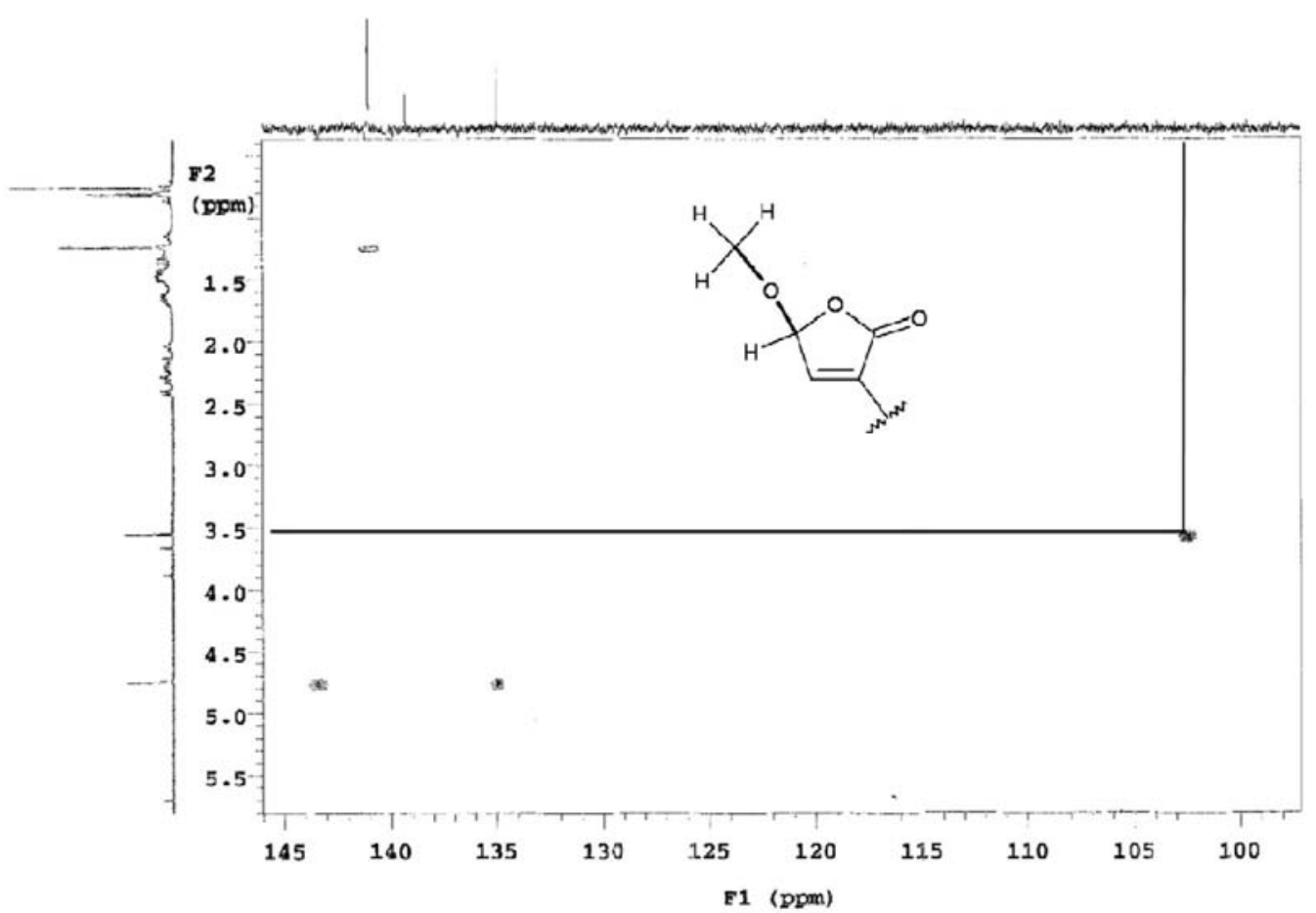

Figure S28. HMBC NMR experiment ( $\mathrm{CDCl}_{3}, 500$ x $\left.125 \mathrm{MHz}, \delta_{\mathrm{C}} 100-145\right)$ of the compounds 3 and 4 isolated of Nanuza plicata. * Correlation of compounds 4 .

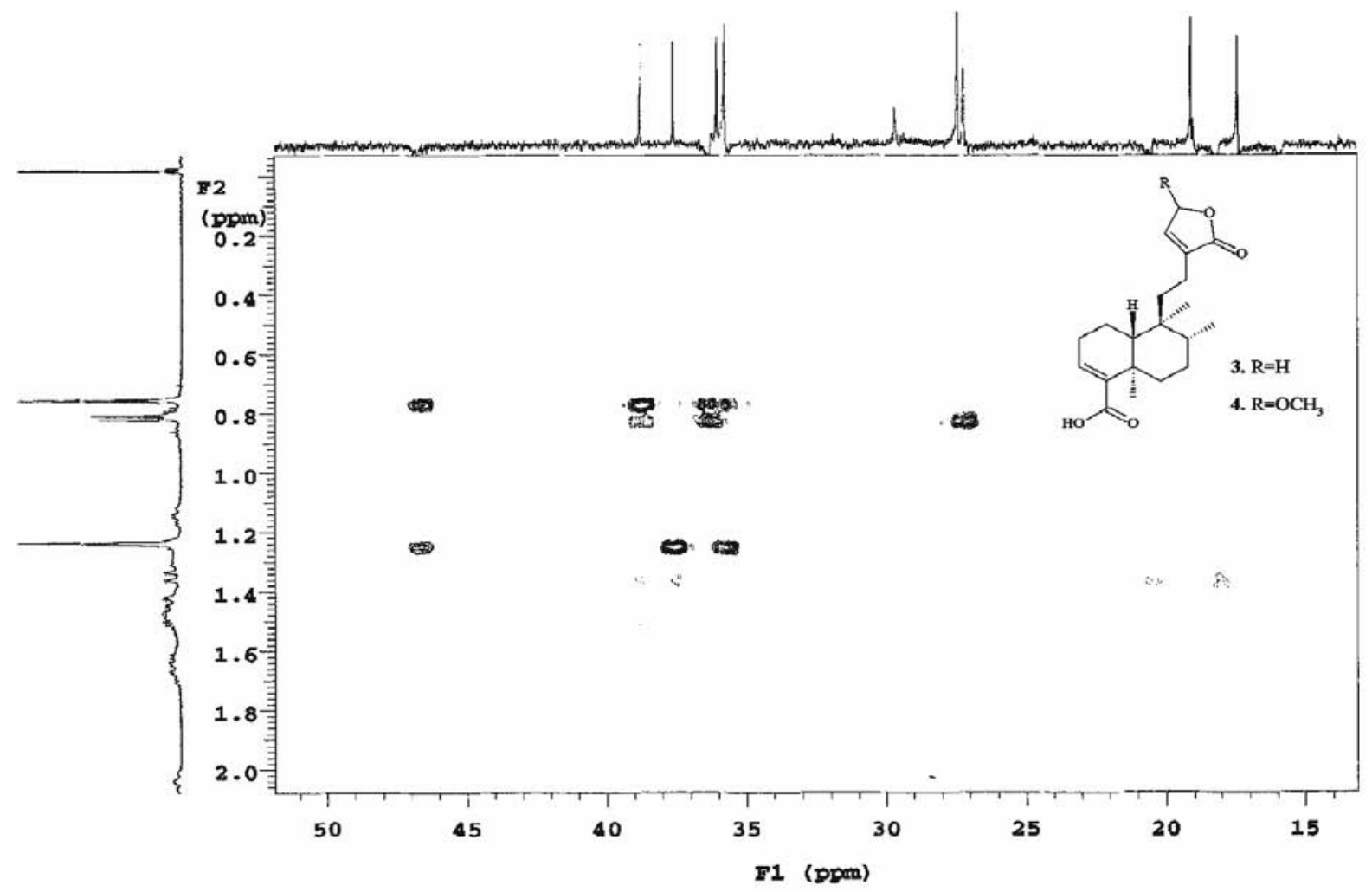

Figure S29. HMBC NMR experiment $\left(\mathrm{CDCl}_{3}, 500 \times 125 \mathrm{MHz}, \delta_{\mathrm{C}} 15-50\right)$ of the compounds 3 and $\mathbf{4}$ isolated of Nanuza plicata. 


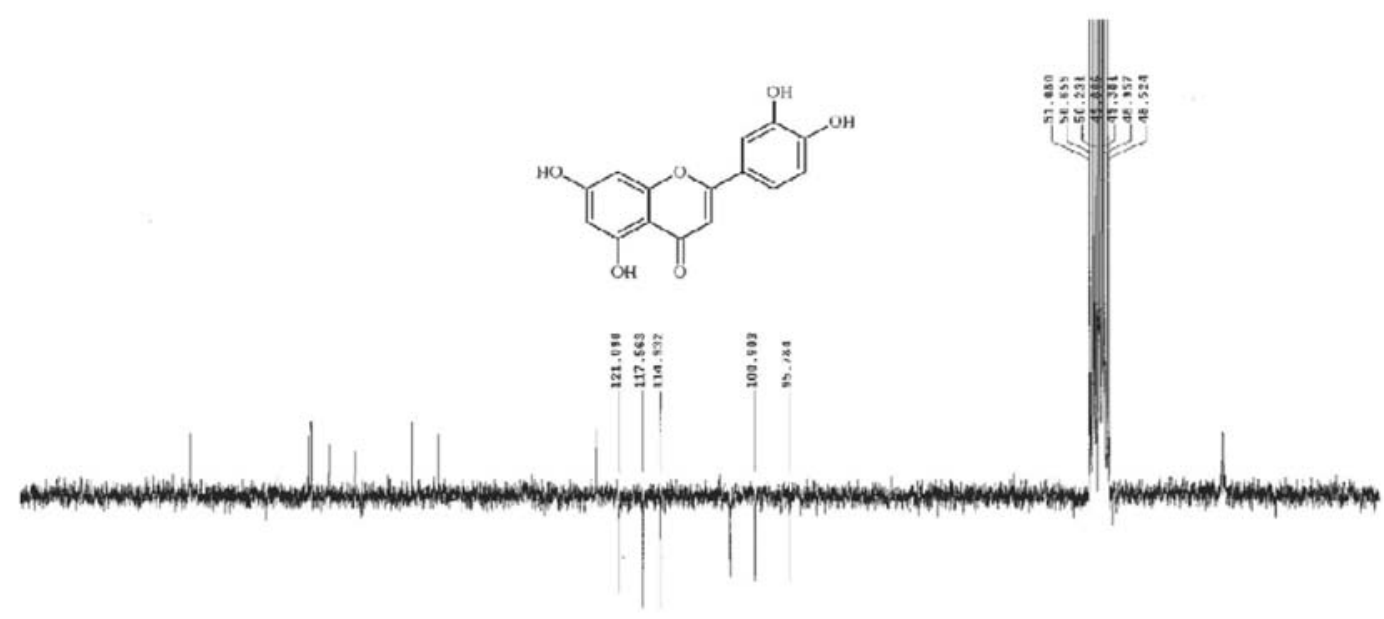

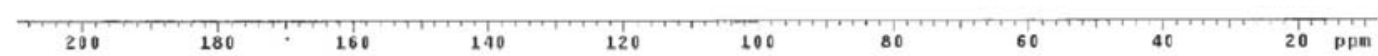

Figure S30. ${ }^{13} \mathrm{C}$ NMR spectrum $\left(\mathrm{CD}_{3} \mathrm{OD}, 125 \mathrm{MHz}\right)$ of the compound 7 isolated of Nanuza plicata.

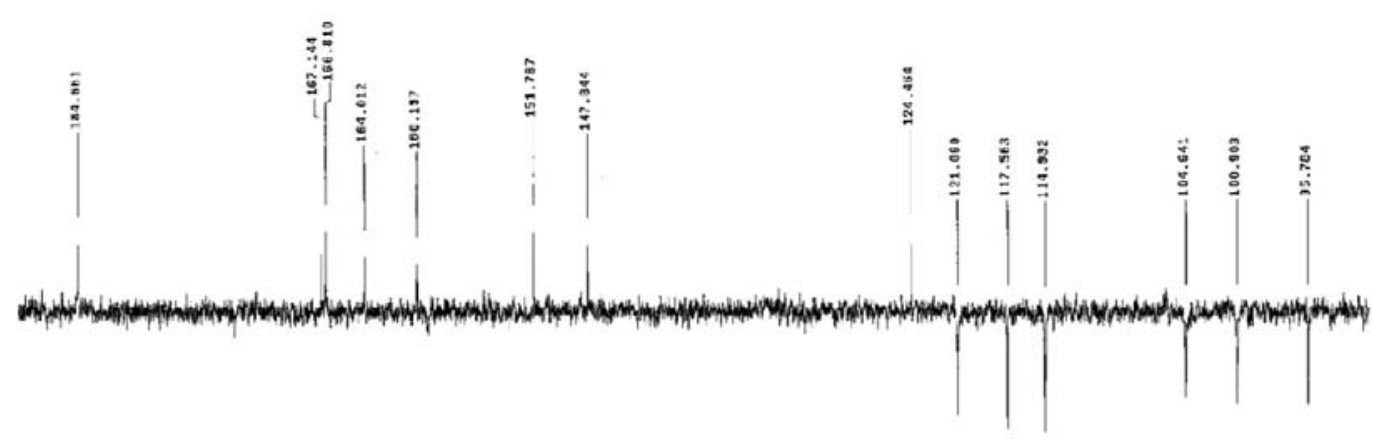

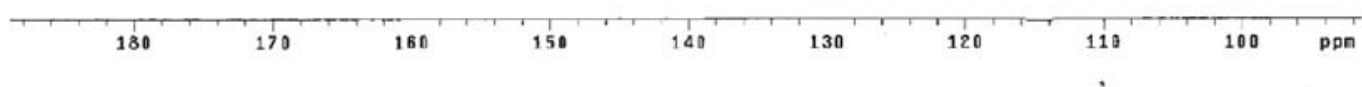

Figure S31. ${ }^{13} \mathrm{C}$ NMR spectrum $\left(\mathrm{CD}_{3} \mathrm{OD}, 125 \mathrm{MHz}, \delta_{\mathrm{C}}\right.$ 95-184) of the compound 7 isolated of Nanuza plicata. 


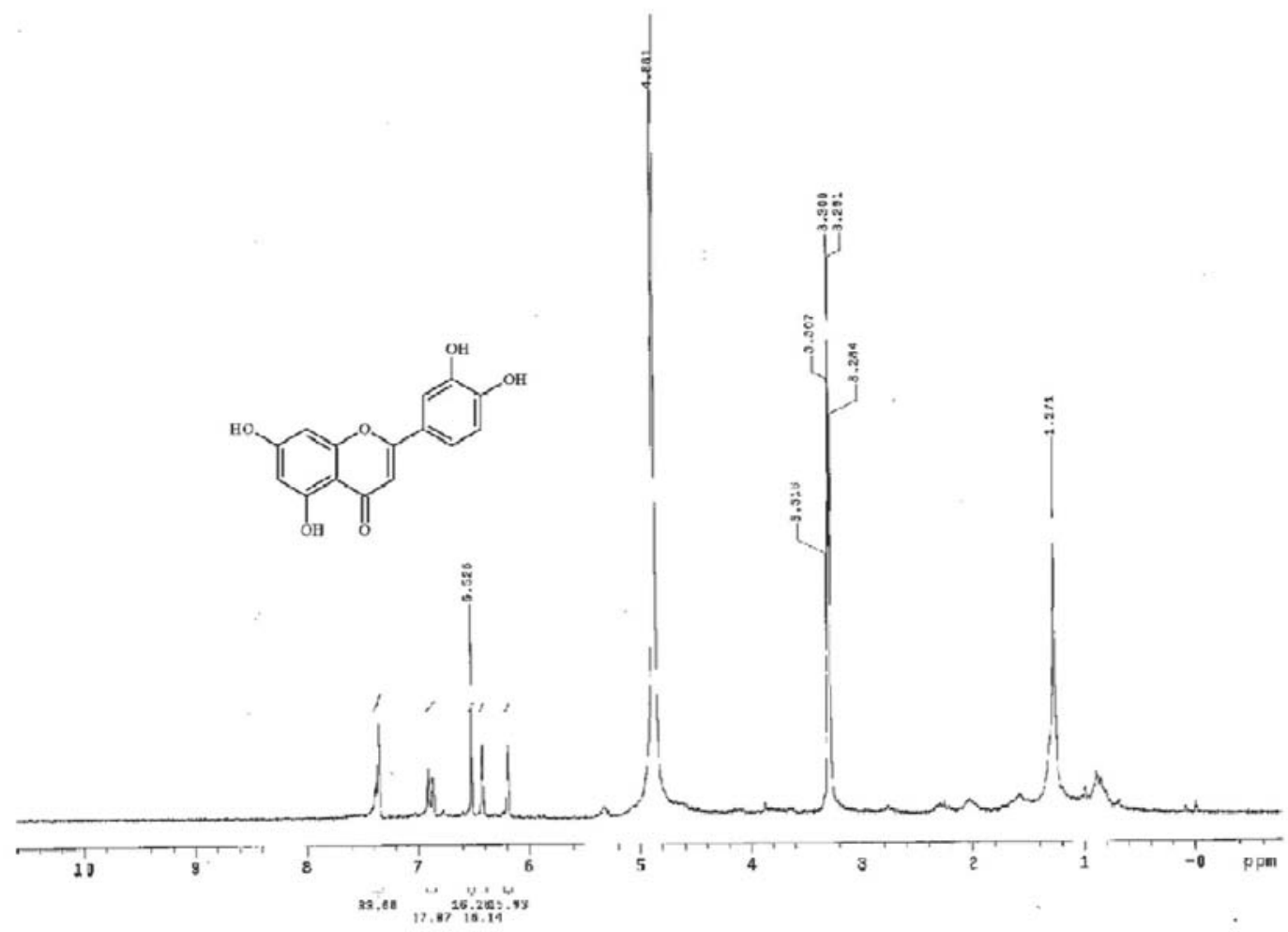

Figure S32. ${ }^{1} \mathrm{H}$ NMR spectrum $\left(\mathrm{CD}_{3} \mathrm{OD}, 500 \mathrm{MHz}\right)$ of the compound 2 isolated of Nanuza plicata.

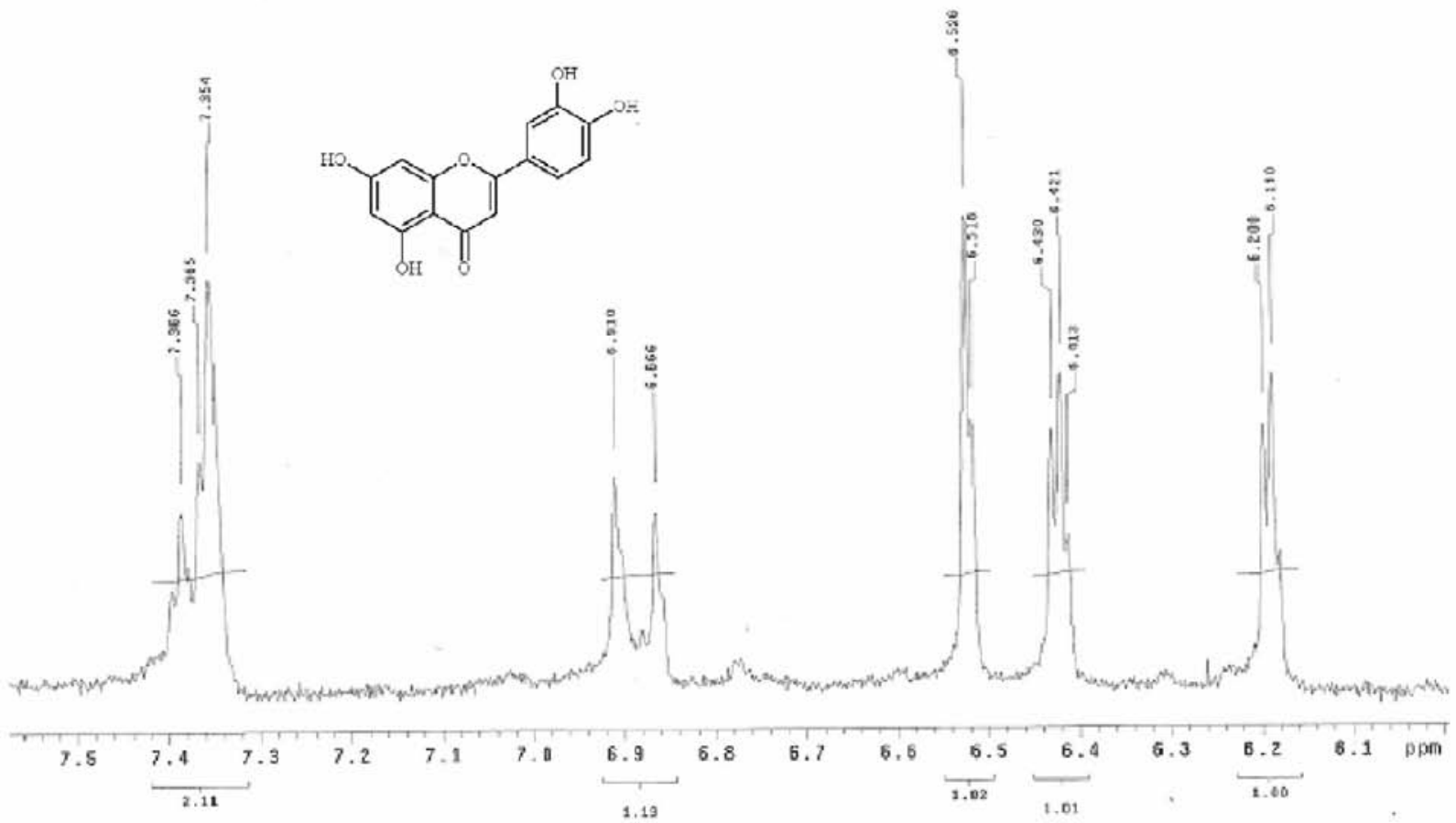

Figure S33. ${ }^{1} \mathrm{H}$ NMR spectrum $\left(\mathrm{CD}_{3} \mathrm{OD}, 500 \mathrm{MHz}, \delta_{\mathrm{H}} 6.1-7.5\right)$ of the compound 7 isolated of Nanuza plicata. 